\title{
Liquefaction hazard mapping in the city of Boumerdès, Northern Algeria
}

\author{
Hamid Bourenane ${ }^{1,2} \cdot$ Youcef Bouhadad ${ }^{1,2} \cdot$ Mohamed Tas $^{2}$
}

Received: 21 September 2016 / Accepted: 28 July 2017 /Published online: 4 September 2017

(C) The Author(s) 2017. This article is an open access publication

\begin{abstract}
The city of Boumerdès, located in Northern Algeria, was badly affected during the May 21, 2003 Zemmouri $(\mathrm{Mw}=6.8)$ earthquake where extensive liquefaction has been reported. The aim of this paper is to assess and to map the liquefaction potential for Boumerdès. We collected and used data from 154 boreholes, 10 down-hole tests, 56 standard penetrations tests (SPT), and inventory of 35 water level points. This data has been analyzed in the framework of geographical information systems (GIS). We assessed the liquefaction potential index (LPI) by considering a seismic hazard scenario corresponding to $\mathrm{a}_{\max }=0.48 \mathrm{~g}$ calculated, using a probabilistic approach, for a return period of 500 years. LPI values have been correlated to compile the liquefaction hazard map that indicates the quantitative characteristics of the liquefiable layers and the induced disruption probability area. Results show that the main part of the city of Boumerdès belongs to a low liquefaction potential area except for a narrow corridor along the Corso waterway, where the liquefaction potential is moderate to high. The obtained results are compatible with the geological, geotechnical and hydrogeological susceptibility to liquefaction of the area. The results also show a good agreement with the observations made after the May 21, 2003 Zemmouri earthquake. The obtained liquefaction hazard maps may serve as useful tools for land management and planning in the city of Boumerdès and
\end{abstract}

Hamid Bourenane

b.hamid@hotmail.com

1 CGS, Centre National de Recherche Appliquée en Génie Parasismique, 1 Rue Kadour Rahim, BP 252 Hussein Dey, Algeria

2 FSTGAT, Université des Sciences et de la Technologie Houari Boumediene Bab Ezzouar (USTHB), Hussein Dey, Algeria as an example of liquefaction hazard assessment that may be applied in other populated cities in northern Algeria's seismic prone areas.

Keywords Liquefaction · Hazard maps · GIS · Seismic hazard · Algeria

\section{Introduction}

Earthquake-induced geological/geomorphological hazards in northern Algeria include several phenomena such as landslides, rock falls, and soil liquefaction (Bouhadad et al. 2010; Bourenane et al. 2014; Bourenane et al. 2016). Soil liquefaction is among the main causes of structures damage in saturated loose sand deposits during earthquakes. Indeed, loose sand tends to compress under cyclic loading imposed by earthquake shaking, which can transfer normal stress from the sand matrix onto the pore water, if the soil is saturated and largely unable to drain during cyclic loading. Hence, a reduction in the effective confining stress within the soil and an associated loss of strength and stiffness occur contributing, consequently, to soil deposit deformation. Past earthquakes showed how soil liquefaction may be damaging for buildings, bridges, railways, harbors, and other infrastructures. Soil liquefaction has been, historically, observed during moderatesized and strong earthquakes (Ambraseys 1988). However, in Algeria, liquefaction is only associated to strong earthquakes of El Asnam $(\mathrm{Ms}=7.3,1980)$ and Zemmouri $(\mathrm{Mw}=6.8$, 2003) (Philip and Meghraoui 1983; Bouhadad et al. 2004; Machane et al. 2004). Investigation in contemporary documents suggests that the 22nd, August 1856 Jijelli earthquake $\left(\mathrm{I}_{0}=\right.$ VIII- IX) triggered tsunamis and liquefaction (Harbi 2001). However, no liquefaction was reported during the several earthquakes of magnitude $\mathrm{M}_{\mathrm{s} .}<6.0$ that occurred 
during this century. Nevertheless, paleoliquefaction is also described in quaternary geological layers triggered likely by ancient pre-historic seismic events (Bouhadad et al. 2008; Benhammouche et al. 2013). During the 2003 Zemmouri earthquake $\left(\mathrm{M}_{\mathrm{w}}=6.8\right)$ liquefaction induced ground deformation has been extensively observed in the most susceptible areas around Boumerdès city, mainly along riversides and along the beach land, where, the geological, geotechnical, and hydrogeological conditions are most favorable (Bouhadad et al. 2004; Machane et al. 2004). It caused damage to roads and settlements of houses and bridges in many places. The described liquefaction features include centimeter to several meters- long fissures, ground settlement and lateral spreading along rivers sides as well as sand boils that constitute a typical feature of liquefaction during this earthquake (Fig. 1). The May 21, 2003 (Mw 6.8) Zemmouri earthquake caused 2384 deaths and widespread damage of buildings. The observed severe ground motion amplitude was, partly, caused by the lithographical and topographical amplification effects of seismic motion (DLEP 2004; Hellel et al. 2010; Dunand et al. 2004; Laouami et al. 2003; Laouami et al. 2006; Meslem et al. 2012; Bensalem et al. 2010). Worldwide, during the last few decades, liquefaction hazard zonation became among the first steps in each seismic risk analysis and mitigation strategy in urban areas. It may constitute a useful guide for a future urbanism development planning in liquefaction prone areas and an important challenge to develop proper disaster management policies. Liquefaction hazard corresponds to the probability of occurrence of liquefaction in a given area within a reference period of time (Varnes 1984), that means identification of areas with high likelihood of liquefaction-induced ground deformation which is among causes of damage during earthquakes. Liquefaction hazard maps are also useful to identify areas where specific investigations for liquefaction hazard are needed or should be required prior to any project development; however, in general such maps should not be used for site-specific engineering design but for land planning only. The aim of this work is to prepare liquefaction hazard maps of the urban area of Boumerdès by using GIS technology. The liquefaction assessment has been conducted, by using field data obtained from boreholes, down-holes, and standard penetration tests, in terms of factor of safety against liquefaction $\left(\mathrm{F}_{\mathrm{S}}\right)$ and liquefaction potential index (LPI). For this purpose two main steps have been followed: (i) Geological, hydrogeological, geotechnical, geophysical, and seismic hazard data gathering (ii) assessment and mapping of liquefaction potential. The outcome of this study is presented, herein, as liquefaction hazard maps indicating the quantitative characteristics of the liquefiable layers and the area where there was a probability of surface liquefaction. GIS technology is used in this research in order to analysis, assess, and build a liquefaction hazard zonation database for the studied area.

\section{Description of the study area}

Boumerdès city, the capital of the Boumerdès prefecture, is located in north central Algeria at about $50 \mathrm{~km}$ east of the capital Algiers and it is a coastal Mediterranean city (Fig. 2). Due to rapid development during the last century, Boumerdès city has become one of the largest urban areas and an important commercial distribution center. The studied area is characterized by a Mediterranean climate, known with cold and rainy winters, with flash floods, from November to March and a hot and dryn season between May to September. The precipitations are irregular and high in winter, averaging $600 \mathrm{~mm} /$ year. The average annual temperature varies between $10^{\circ} \mathrm{C}$ and $27^{\circ} \mathrm{C}$. Geomorphologically, the city of Boumerdès altitude ranges between $30 \mathrm{~m}$ and $50 \mathrm{~m}$ above sea level. The city is crossed by three rivers which are, respectively, Oued Boumerdès river in the east, Oued Tatareg river in the center, and the Oued Corso in the West (Fig. 2).

\section{Methodology}

The adopted methodology for evaluating and mapping the liquefaction potential in Boumerdès city includes (05) five steps: (i) Collection and analysis of geological, hydrogeological, geotechnical, and geophysical data of the study area including field observations and elaboration of data base entitled (Boumerdès_Data_Based Géo_Map) using GIS system (Ms Access, ArcGIS and MapInfo); (ii) Perform seismotectonic, seismicity, and probabilistic seismic hazard analysis for the study area; (iii) Preparation of representative geological and geotechnical profiles based on the geological and geotechnical data; (iv) Evaluation of the liquefaction potential index (LPI) of the soil layers using geotechnical parameters provided by borings and SPT taking into consideration a seismic hazard scenario corresponding to the calculated seismic hazard for a return period of 500 years which is $\mathrm{a}_{\max }=0.48 \mathrm{~g}$ and finally, (v) Preparation of the liquefaction hazard maps for the city of Boumerdès by correlation between results of the liquefaction index (LPI) in the framework of a geographical information system (GIS). In addition, having computed the value of probability based on the LPI, a liquefaction appearance probability map was compiled for the considered seismic scenario.

\section{Seismotectonic setting}

The Boumerdès region belongs to the central part of the Tell Atlas chain of northern Algeria characterized by a NW-SE convergence of the African and the Eurasian tectonic plates. The amount of crustal shortening ranges from 4 to $8 \mathrm{~mm} /$ year (McKenzie 1972; Argus et al. 1989; 
Fig. 1 Photographs showing different types of liquefaction features occurred during the May 21, $2003(\mathrm{Mw}=6.8)$ Zemmouri earthquake. a) Surface manifestation of liquefaction in Zaatra valley (Zemmouri). b) Lateral spreading occurred along the Oued Isser riverside. c) Cumulated collapse of soil caused by liquefaction in Oued Isser river valley. d) Soil collapse caused by liquefaction in the Legata region. Locations of figures (a-d) are shown on Fig. 10
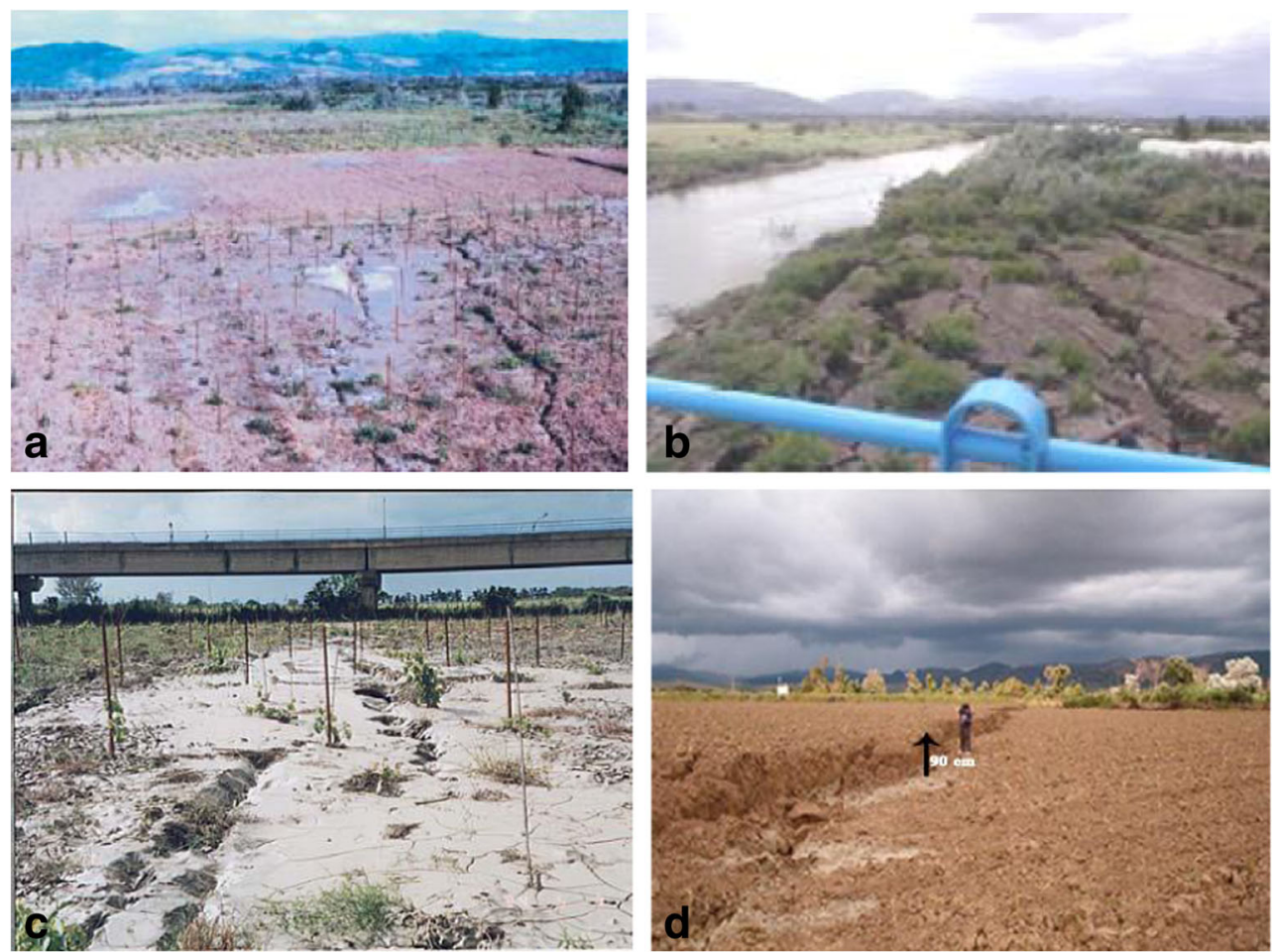

Nocquet and Calais 2004). As a consequence of this geodynamic process a series of active faults trending NESW affects the Tell Atlas chain (Meghraoui et al. 1988; Meghraoui 1991; Aoudia and Meghraoui 1995; Bouhadad 2001; Meghraoui et al. 2004; Maouche et al. 2011, Bouhadad 2013; Maouche et al. 2013). These multi-segment faults were responsible for several strong earthquakes in the past (Philip and Meghraoui 1983; Meghraoui et al. 2004) and are likely to produce strong seismic events in the future (Bouhadad and Laouami 2002). Several historical strong earthquakes have been mentioned in the available seismicity catalogs of Algeria (Benouar 1994; CRAAG 1994; Ayadi et Bezzeghoud, 2015). The city of Boumerdès considered, before the May 21, $2003(\mathrm{Mw}=6.8)$ earthquake, as a seismically quite and safe area, has to consider now the impact of major active faults recently revealed and/or identified both offshore and onshore (Bouhadad et al. 2004; Meghraoui et al. 2004; Deverchère et al. 2005; Benfedda et al. 2017). Indeed, the Zemmouri 2003 earthquake revealed a $50 \mathrm{~km}$ long active reverse fault, located offshore, oriented NE-SW and dipping $50^{\circ}$ to the SW (Bounif et al. 2004; Meghraoui et al. 2004; Belabbes et al. 2009). After this seismic event Boumerdès city is now reclassified in zone III, corresponding to the highest hazard zone in the new Algerian seismic code classification (RPA 2003). The recorded peak ground accelerations during the May 21, 2003 $(\mathrm{Mw}=6.8)$ Zemmouri earthquake reached $0.58 \mathrm{~g}$ (amplified value by site conditions) and $0.34 \mathrm{~g}$ (non amplified value) at $20 \mathrm{~km}$ far from the epicenter (Laouami et al. 2003; Laouami et al. 2006) (Fig. 3).

\section{Seismic hazard analysis}

In order to provide the PGA value to use in this study we perform a seismic hazard analysis by using a probabilistic approach (Cornell 1968; Mc Guire 1978; NRC 1988; Geomatrix 1993; Sadigh et al. 1993). For that three steps are required: (i) Definition of a seismic source model, (ii) Determination of source parameters, (iii) Choice of attenuations relationship and, finally, computation of seismic hazard. The seismic source model and source parameters have been determined based on the most recent seismotectonic data of the region, as shown, respectively, on Fig. 4 and Table 1 and by using the probabilistic approach. Concerning the attenuation of ground motion we used the most recent available attenuation relationships of Ambraseys et al. (2005), which is an update of the Ambraseys and Bommer (1991) relationship and the Akkar and Bommer (2010). The obtained result is shown in Fig. 5. The used earthquake scenario in this study is $0.48 \mathrm{~g}$ which is the peak ground acceleration obtained for a return period of 500 years by combining the used attenuation relationships mentioned above. In the probabilistic approach of seismic hazard analysis used in this study, it is assumed that the occurrence of earthquakes in a seismic source results from a Poisson process. Then, the 
Fig. 2 Geographical location and digital elevation model (DEM) of the studied area with the urban perimeter boundaries of Boumerdès city
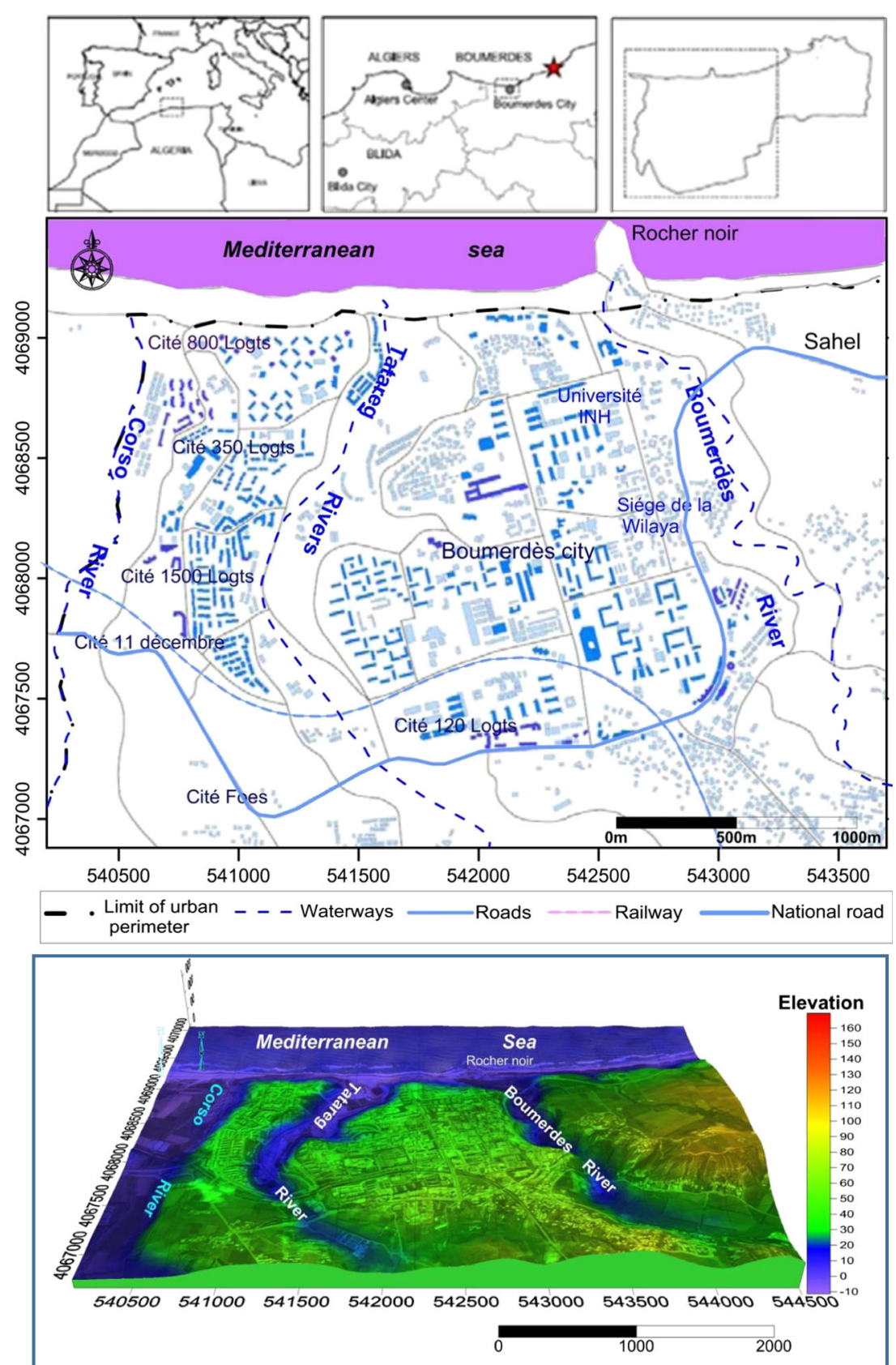

probability that at a given site a ground motion parameter, $Z$, will exceed a specified level, $z$, during a specified time, $\mathrm{T}$, is represented by the expression:

$P(Z \succ z)=1.0-\exp (-\nu(z) \cdot T) \leq \nu(z) \cdot T$

Where $v(z)$ is the average frequency during time period $T$ at which the level of ground motion parameter, $Z$, exceeds level $\mathrm{z}$ at a given site. The function $v(\mathrm{z})$ incorporates the uncertainty in time, size, and location of future earthquakes and uncertainty in the level of ground motion they produce at the site (Geomatrix 1993).
Geological, hydrogeological, and geotechnical data: spatial data base

In order to assess liquefaction hazard, the available in situ investigations geological, geotechnical, and hydrogeological data, carried out by several companies (L.C.T.P 1988-2003; L.N.H.C 1980-2010; GEOMICA and ANRH 2007), in the framework of several construction project studies, have been compiled, analyzed, and processed. It consists of 10 down-hole, 154 boreholes and hydraulic drilling of depth ranging between 10 to $35 \mathrm{~m}$, geotechnical profiles containing data about the $\mathrm{N}$ values of SPT, grain size distribution, liquidity limit (LL), and plasticity limit (PL) of selected samples in subsoil layers as well 


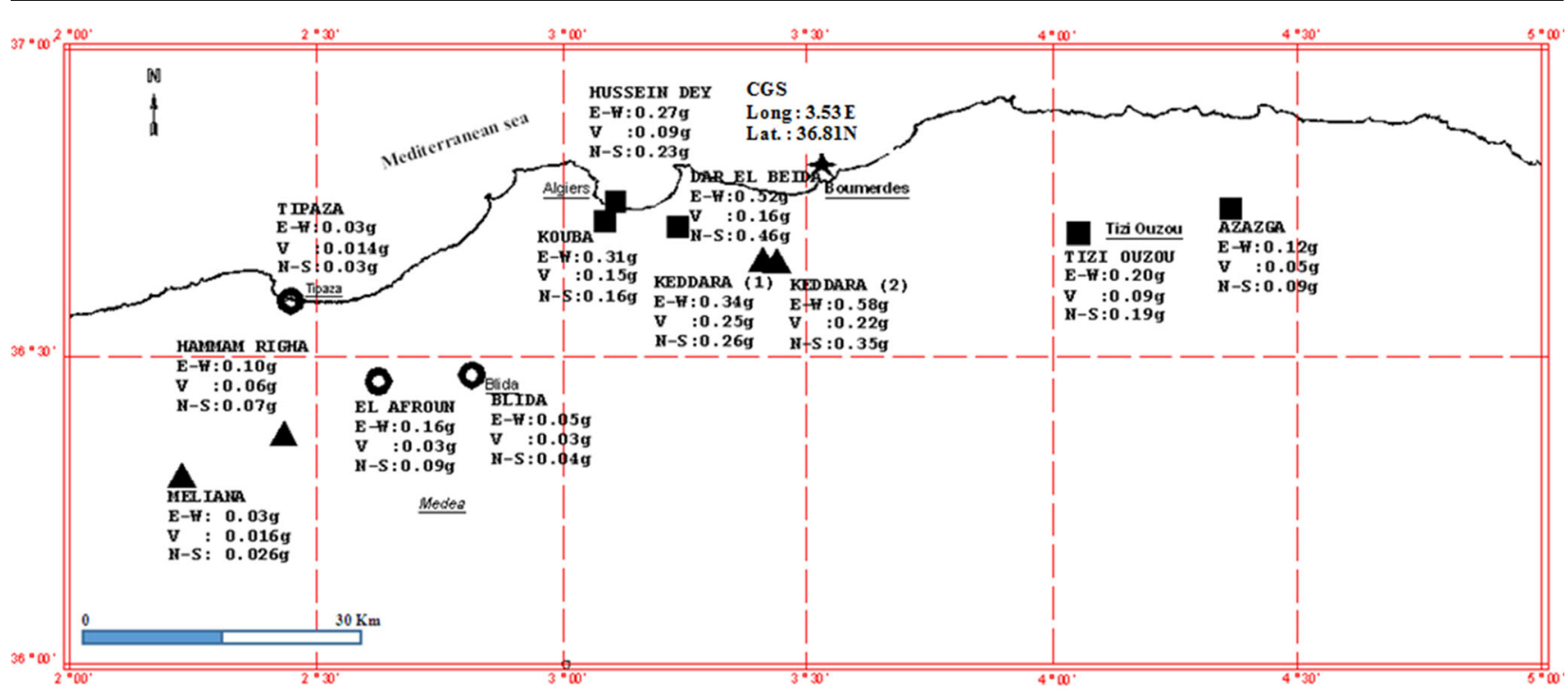

A Digital stations E TNA ODigital stations SSA-1 Digital stations SMA-1

Fig. 3 Epicenter location (see the star) of the May 21, $2003(\mathrm{Mw}=6.8)$ Zemmouri earthquake and the CGS accelerograph network that recorded the mainshock of earthquake (Laouami et al. 2003; Laouami et al. 2006)

as 35 level checks (water table depth) of water points. The data from boreholes were used to prepare simplified cross-sections illustrating the lithological structure of the studied area. The locations of boreholes, SPT, down-hole, water points, and the position of cross-sections are shown in Fig. 6. The data analysis required a coding in a data base (Boumerdès_Data_Base and Geo_Map) under GIS framework that allows easy handling, processing, managing, exploiting, treating, and interpreting

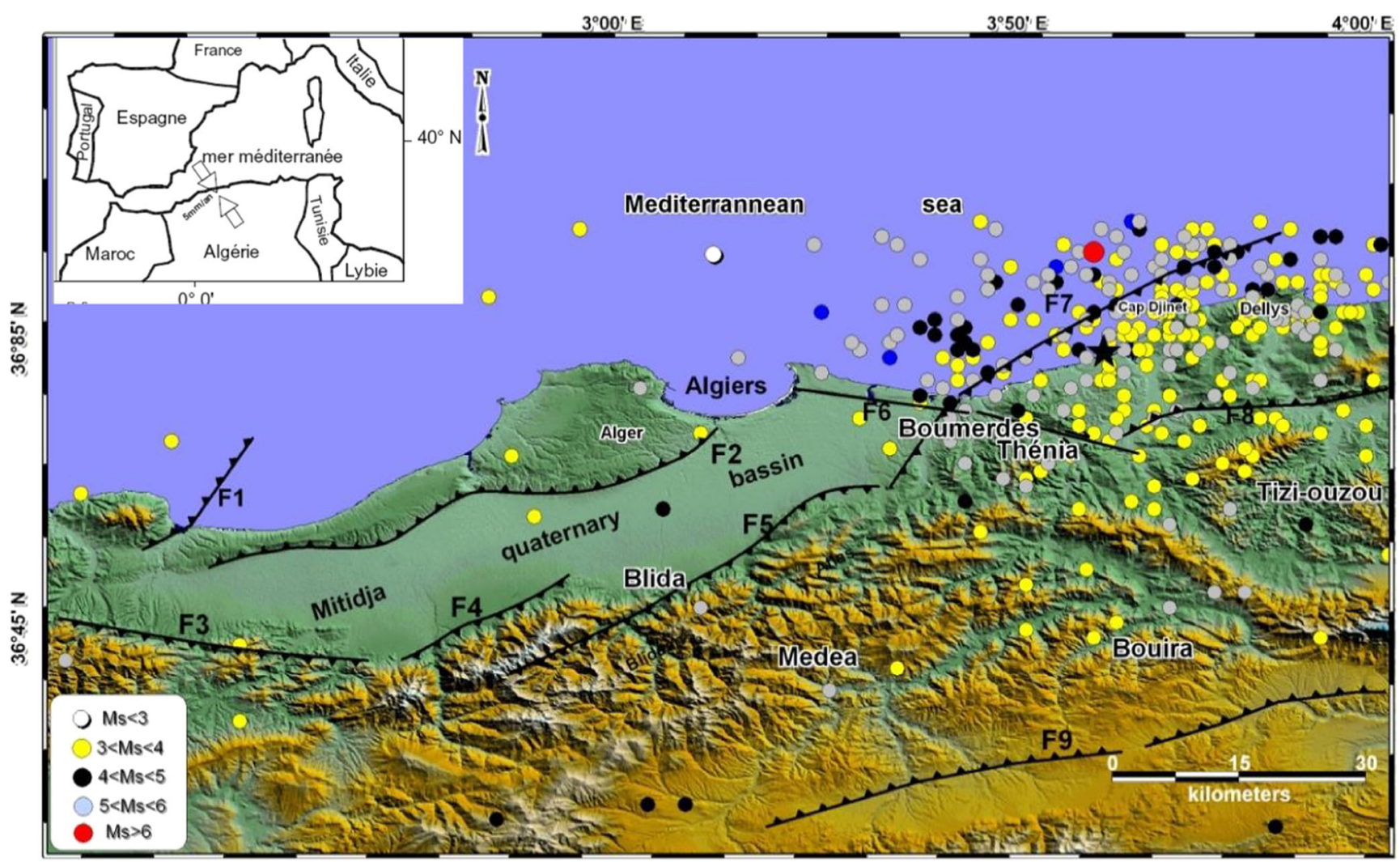

Fig. 4 Seismotectonic model used for seismic hazard analysis. F1, Chenoua fault; F2, Sahel fault; F3, Oued Djer fault; F4, Blida fault; F5, Sud Mitidja fault; F6, Thénia fault; F7, Zemmouri fault; F8, Isser-Tizi- ouzou fault; F9, Boumaad fault. The star indicates the relocated May 21, $2003(\mathrm{Mw}=6.8)$ earthquake epicenter (Bounif et al. 2004) 
Table 1 Active faults parameters considered in the seismic hazard analysis

\begin{tabular}{|c|c|c|c|c|c|c|}
\hline Faults & Activity & Mechanism & $\begin{array}{l}\text { Depth } \\
(\mathrm{km})\end{array}$ & $\begin{array}{l}\text { Magnitude } \\
\text { (Mmax) }\end{array}$ & $\begin{array}{l}\text { Rate } \\
\mathrm{mm} / \mathrm{yr}\end{array}$ & b-value \\
\hline \multirow{3}{*}{$\begin{array}{l}\text { Chenoua fault } \\
\text { (F1) }\end{array}$} & \multirow[t]{3}{*}{1.0} & \multirow[t]{3}{*}{ reverse } & 10 & $6.0(.6)$ & $0.7(.45)$ & $0.65(.2)$ \\
\hline & & & 12 & $6.5(.2)$ & $2.0(.45)$ & $0.80(.6)$ \\
\hline & & & 15 & $6.75(.2)$ & $3.5(.10)$ & $0.95(.2)$ \\
\hline \multirow{3}{*}{$\begin{array}{l}\text { Sahel fault } \\
\text { (F2) }\end{array}$} & \multirow[t]{3}{*}{0.8} & \multirow[t]{3}{*}{ reverse } & 10 & $6.0(.6)$ & $0.7(.45)$ & $0.65(.2)$ \\
\hline & & & 12 & $6.5(.2)$ & $2.0(.45)$ & 0.80 \\
\hline & & & 15 & $7.3(.2)$ & $3.5(.10)$ & $0.95(.2)$ \\
\hline \multirow{3}{*}{$\begin{array}{l}\text { Oued Djerfault } \\
\text { (F3) }\end{array}$} & \multirow[t]{3}{*}{0.8} & \multirow[t]{3}{*}{ Strike slip } & 10 & $5.5(.6)$ & $0.7(.45)$ & $0.65(.2)$ \\
\hline & & & 12 & $6.0(.2)$ & $2.0(.45)$ & $0.80(.6)$ \\
\hline & & & 15 & $6.5(.2)$ & $3.5(.10)$ & $0.95(.2)$ \\
\hline \multirow{3}{*}{$\begin{array}{l}\text { Blida fault } \\
\text { (F4) }\end{array}$} & \multirow[t]{3}{*}{0.8} & \multirow[t]{3}{*}{ reverse } & 10 & $6.0(.6)$ & $0.7(.45)$ & $0.65(.2)$ \\
\hline & & & 12 & $6.5(.2)$ & $2.0(.45)$ & $0.80(.6)$ \\
\hline & & & 15 & $6.75(.2)$ & $3.5(.10)$ & $0.95(.2)$ \\
\hline \multirow{3}{*}{$\begin{array}{l}\text { Sud Mitidja fault } \\
\text { (F5) }\end{array}$} & \multirow[t]{3}{*}{0.8} & \multirow[t]{3}{*}{ reverse } & 10 & $6.0(.6)$ & $0.7(.45)$ & $0.65(.2)$ \\
\hline & & & 12 & $6.5(.2)$ & $2.0(.45)$ & $0.80(.6)$ \\
\hline & & & 15 & $6.75(.2)$ & $3.5(.10)$ & $0.95(.2)$ \\
\hline \multirow{3}{*}{$\begin{array}{l}\text { Theniafault } \\
\text { (F6) }\end{array}$} & \multirow[t]{3}{*}{0.8} & \multirow[t]{3}{*}{ Strike slip } & 10 & $6.0(.6)$ & $0.7(.45)$ & $0.65(.2)$ \\
\hline & & & 12 & $6.5(.2)$ & $2.0(.45)$ & 0.80 \\
\hline & & & 15 & $6.75(.2)$ & $3.5(.10)$ & $0.95(.2)$ \\
\hline \multirow{3}{*}{$\begin{array}{l}\text { Zemmouri fault } \\
\text { (F7) }\end{array}$} & \multirow[t]{3}{*}{1.0} & \multirow[t]{3}{*}{ reverse } & 10 & $6.0(.75)$ & $0.7(.5)$ & $0.85(.2)$ \\
\hline & & & 12 & $6.8(.20)$ & $2.0(.25)$ & 0.78 \\
\hline & & & 15 & $7.3(.05)$ & $3.5(.25)$ & $0.65(.2)$ \\
\hline \multirow{3}{*}{$\begin{array}{l}\text { Isser-Tizi-ouzoufault } \\
\text { (F8) }\end{array}$} & \multirow[t]{3}{*}{0.8} & \multirow[t]{3}{*}{ reverse } & 10 & $6.0(.6)$ & $0.7(.45)$ & $0.65(.2)$ \\
\hline & & & 12 & $6.5(.2)$ & $2.0(.45)$ & 0.80 \\
\hline & & & 15 & $7.0(.2)$ & $3.5(.10)$ & $0.95(.2)$ \\
\hline \multirow{3}{*}{$\begin{array}{l}\text { Boumaadfault } \\
\text { (F9) }\end{array}$} & \multirow[t]{3}{*}{0.8} & \multirow[t]{3}{*}{ reverse } & 10 & $5.5(.6)$ & $0.14(.4)$ & $0.65(.2)$ \\
\hline & & & 12 & $6.0(.2)$ & $0.70(.4)$ & 0.80 \\
\hline & & & 15 & $6.5(.2)$ & $3.50(.2)$ & $0.95(.2)$ \\
\hline
\end{tabular}

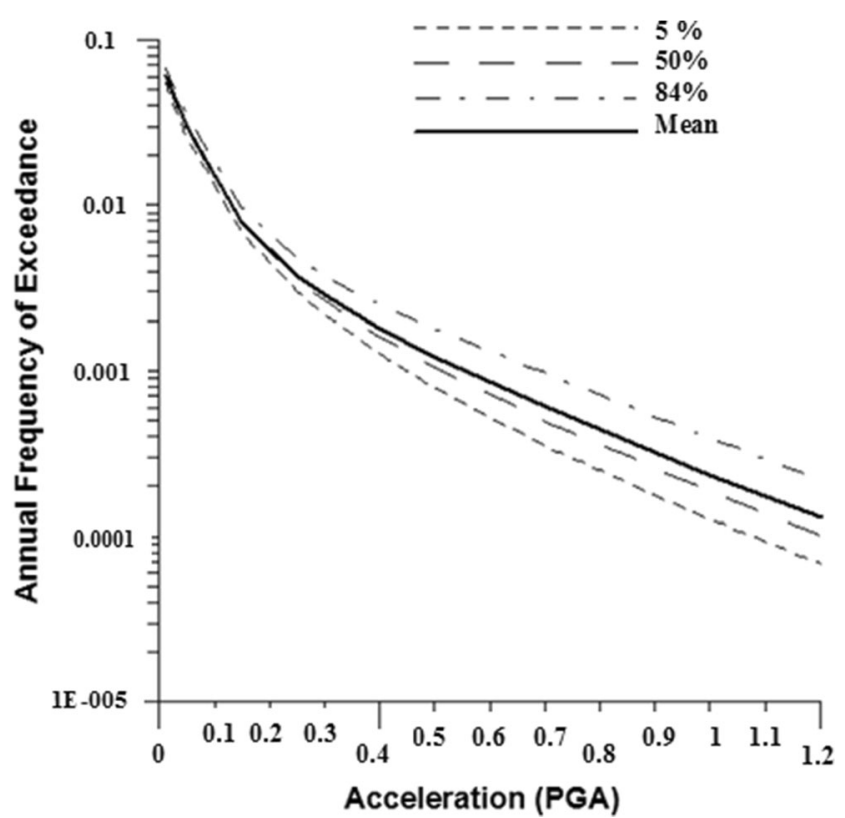

Fig. 5 Seismic hazard curves for the Boumerdès site $(x=3.468$, $y=36.764$ ) the large amount of data. It allows the needed capacity of spatial analysis, data management, and updates as well as mapping (Carrara et al. 1995; Ayalew et al. 2005). For this purpose we perform a geological, geotechnical, and hydrogeological data base using MapInfo and ArcGis softwares and Microsoft access. All the maps with database were geo-referenced at the same local projection system of Algeria (UTM zone 31 North, WGS 84 Geodetic Reference System).

\section{Geological conditions}

The studied area is, geologically, characterized by the metamorphic basement overlain by Mio-Pliocene and Quaternary clays and sand deposits (Fig. 7). The metamorphic basement that outcrops in the eastern part is mostly constituted by micashistes and quartzites (Ficheur 1895; CGS 2009). The basement is at a depth of 3 to $6 \mathrm{~m}$ as shown on the cross section AA' (Fig. 9) and uncomfortably covered by Miocene clay and marl and Plaisancian blue marls. The geometry of the top of blue marls is shown on the cross sections of Fig. 9. We can see that the depth of 
Fig. 6 The location of boreholes, down-holes, water level points, and cross-sections

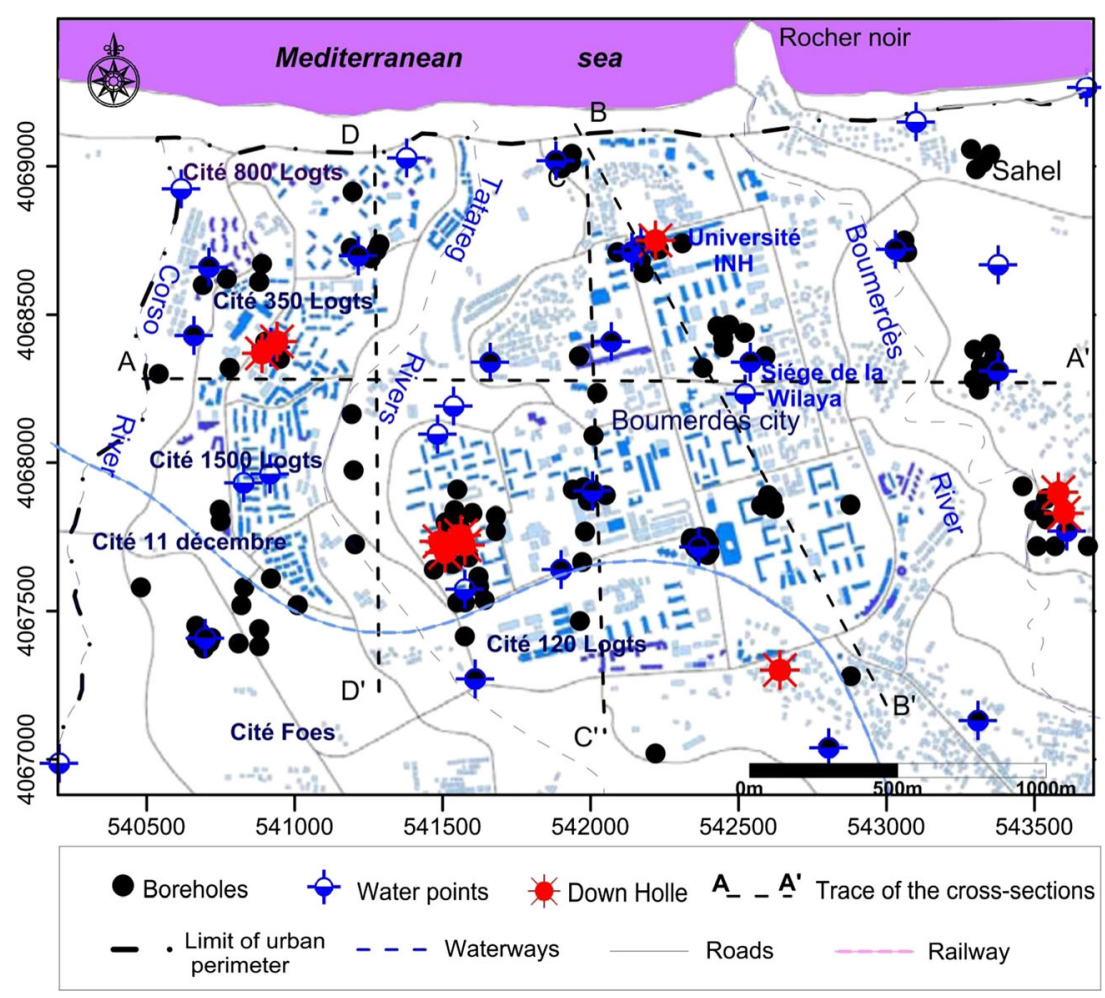

the marl layer decreases from the north to the south from $32 \mathrm{~m}$ to $3 \mathrm{~m}$ (see the cross sections BB', CC', and DD' of Fig. 9) and from the west to the east from $26 \mathrm{~m}$ to $2 \mathrm{~m}$. The Quaternary deposits overlie the Plaisancian bleu marls and the metamorphic basement. They constitute, almost, the whole surface of the studied area as shown on Fig. 9 (see the cross sections AA', BB', CC', and
DD') and are represented by the following: (i) Pleistocene red sand (as) principally formed by clayey sand deposit, (ii) recent Holocene alluviums $\left(\mathrm{a}_{2}\right)$ mainly along waterways, formed by a $50 \mathrm{~m}$ thick layer of sand, gravels, and clays in Corso plain (Osmani and Ouzerara 2004) and (iii) the recent sandy dune(ad) and sandy beach (a) outcropping along the coastline.

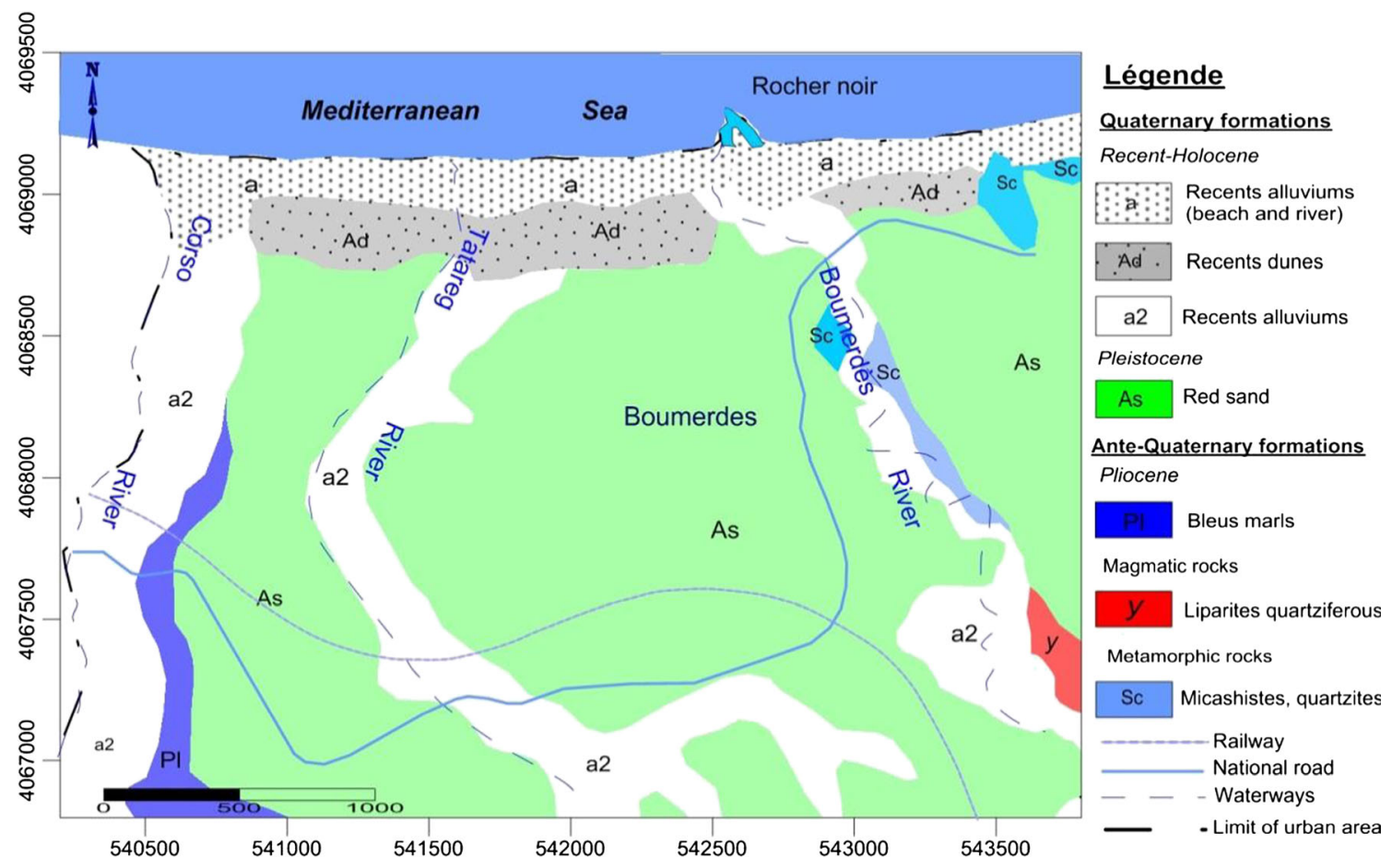

Fig. 7 Geological map of Boumerdès city (Ficheur 1895) 
Fig. 8 Static level (SL) map of the groundwater table in Boumerdès city

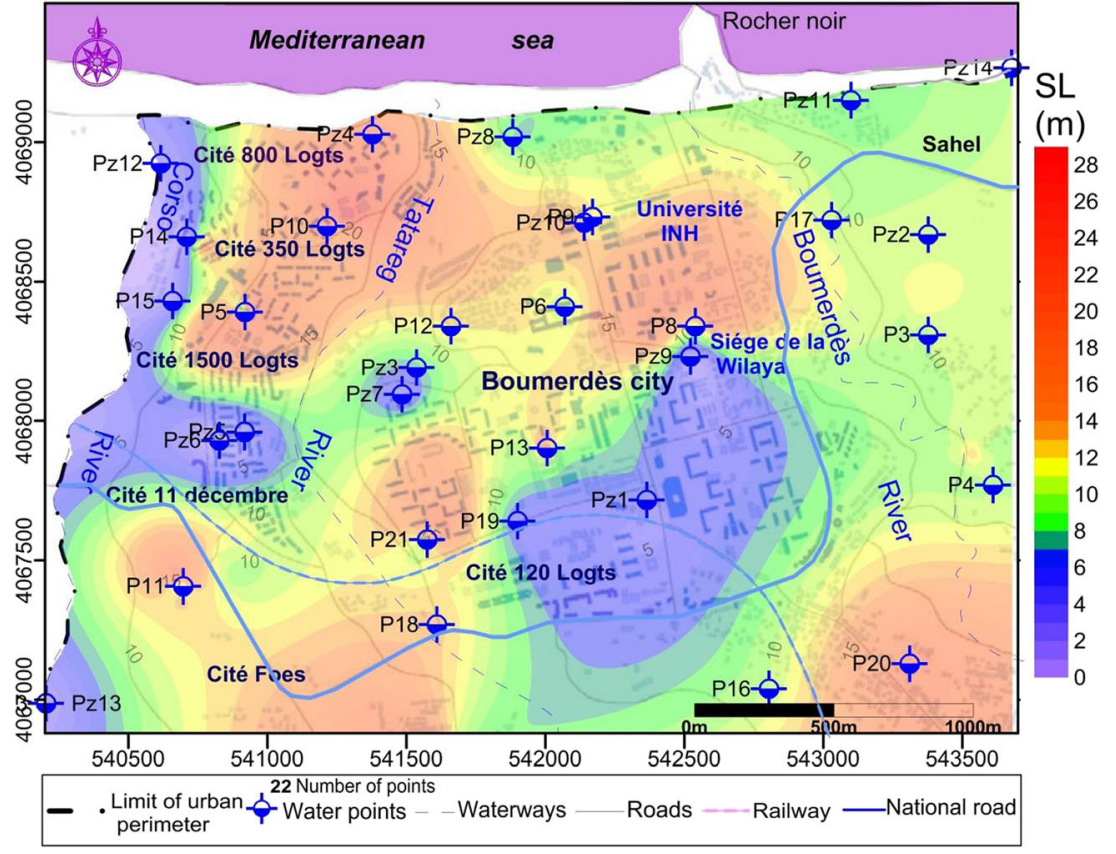

\section{Hydrogeological conditions}

Piezometric data analysis performed in April 2007 (A.N.R.H 2007; L.C.T.P 1988-2003; L.N.H.C 1980-2010), for high water season concerning 35 water points ( 19 wells, two drillings, 14 piezometers) shows that the static level of the groundwater table ranges between 6 to $20 \mathrm{~m}$ in the quaternary red sands and between $0.5 \mathrm{~m}$ to $6 \mathrm{~m}$ near the waterways (Fig. 8) which constitutes a free aquifer in the Quaternary alluvial deposits of the Boumerdès area (CGS 2009; Bourenane 2010). These estimated depths are minimal (surface) and they could be deeper during the dry seasons. The groundwater level is closely associated with the amount of precipitation and may be quite high when the monthly precipitation is high. The values of the hydro-isohypses curves increase from the South to North highlighting a general underground flow toward the North. The isopiezes curves are spaced in the South and tightened toward the valleys (Corso and Boumerdès waterways). The schematized flow reveals, thus, a watershed (piezometric peak) justifying a substratum which goes up. This agrees well with the boreholes data, highlighting the depth of the impermeable bleu marls layer beneath red sands at less than $10 \mathrm{~m}$ the south and more than $10 \mathrm{~m}$ in the north of the city. The shallow water table in the study area increases the susceptibility of the loose deposits to liquefaction during an expected earthquake.

\section{Geotechnical conditions}

Lithological cross sections analysis (Fig. 9, profiles $\mathrm{BB}^{\prime}, \mathrm{CC}^{\prime}$, and $\mathrm{DD}^{\prime}$ ) show that the city of Boumerdès, is mainly, built on quaternary deposits represented by Pleistocene clayey sand and recent Holocene alluvial deposits that overlie the Plaisancian marls. The surveys reveal that the Pleistocene formations are formed by two lithological units (Fig. 10): (a) sandy mud with clay intercalations and (b) 12 to $32 \mathrm{~m}$ thick coarse sand, thicker to the north (cross section CC' and DD'). The thickness also decreases toward the south of the city (cross section CC' and DD') where the basement outcrops (cross section AA'). The statistical analysis of the geotechnical data shows a great variability of the geotechnical characteristics related to the lithological variation of the formations (CGS 2009; Bourenane 2010). The sandy dunes outcropping along the littoral are made of fine and coarse sand with an average thickness of $12 \mathrm{~m}$. The grain size is uniform with an average of fine content percentage lower than $20 \%$. The thick sandy dunes layers are considered as non-plastic soils, the liquidity limit (LL) ranges between $30 \%$ to $41 \%$ with an average of $35 \%$ while the plasticity limit (PL) in this layer varies from $15 \%$ to $21 \%$ (Table 2). The SPT-N values range between 9 to 60 with an average of 44 (Fig. 11). The shear velocity (Vs) value range between 240 to $500 \mathrm{~m} / \mathrm{s}$ suggests a loose soil (S3 type) according to the Algerian seismic code classification (RPA 2003). The sand clayey layers with an average of $36 \%$ fines are classified as moderate plasticity clays while their liquidity limit and plasticity limit are, respectively, $13 \%$ to $52 \%$ and $5 \%$ to $55 \%$ (Table 2). The $\mathrm{N}$ values of these layers range from 4 to 60 with an average of 32 . The shear velocity (Vs) ranges within the interval of $(172 \leq \mathrm{Vs} \leq 730 \mathrm{~m} / \mathrm{s})$ with a mean value of $\mathrm{Vs} \geq 500 \mathrm{~m} / \mathrm{s}$ that suggests a firm soil (S2 type). Moreover, the $\mathrm{H} / \mathrm{V}$ spectral ratios measurements carried out in Boumerdès urban area (Guiller et al. 2004) indicate that $\mathrm{Vs} \geq 500 \mathrm{~m} / \mathrm{s}$. The Holocene alluviums, mainly along waterways are formed by 2 to $9 \mathrm{~m}$ thick sand, gravels, and clays. 
Fig. 9 Borehole profiles in various directions in the studied area (location is shown in Fig. 6)
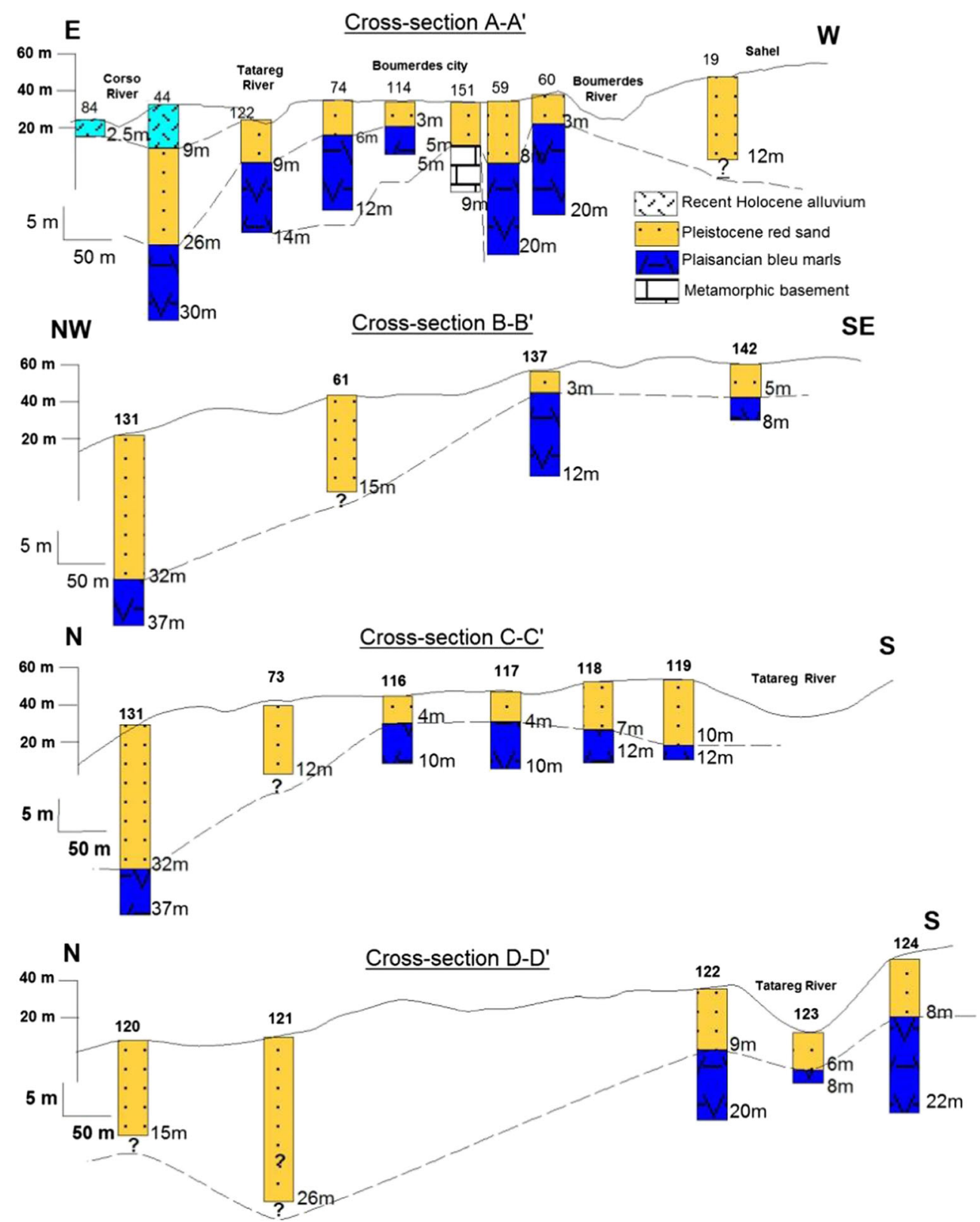

They present $60 \%$ of fines in which the liquidity and plasticity limits are, respectively, $47 \%$ and $24 \%$ and the SPTN values range from 9 to 60 . The $\mathrm{N}$ values ranges from 8 to 11 near the surface to $12-30$ at depth. The Vs values range between 170 and $360 \mathrm{~m} / \mathrm{s}$ indicating a loose soil (S3 type).

\section{Liquefaction susceptibility analysis}

Liquefaction susceptibility is a first step in the liquefaction hazard assessment of a given area. Soil liquefaction susceptibility depends on geological, hydrogeological, and geotechnical site conditions (Youd and Perkins 1978; AFPS 1995; Youd 1998; CDMG 1999; Seed et al. 2003).

\section{Geological and hydrogeological susceptibility}

The soil liquefaction susceptibility depends on the age of the deposits and the depth of the static groundwater table (Youd and Perkins 1978; AFPS 1995). Usually, liquefaction concerns the Holocene deposits where the depth of water table is less than $10 \mathrm{~m}$. According to Youd and Perkins (1978), AFPS (1995), and CDMG (1999), an area is characterized as a liquefaction zone when meeting one or more of the following criteria: (i) Evidence of historical liquefaction occurrences; 


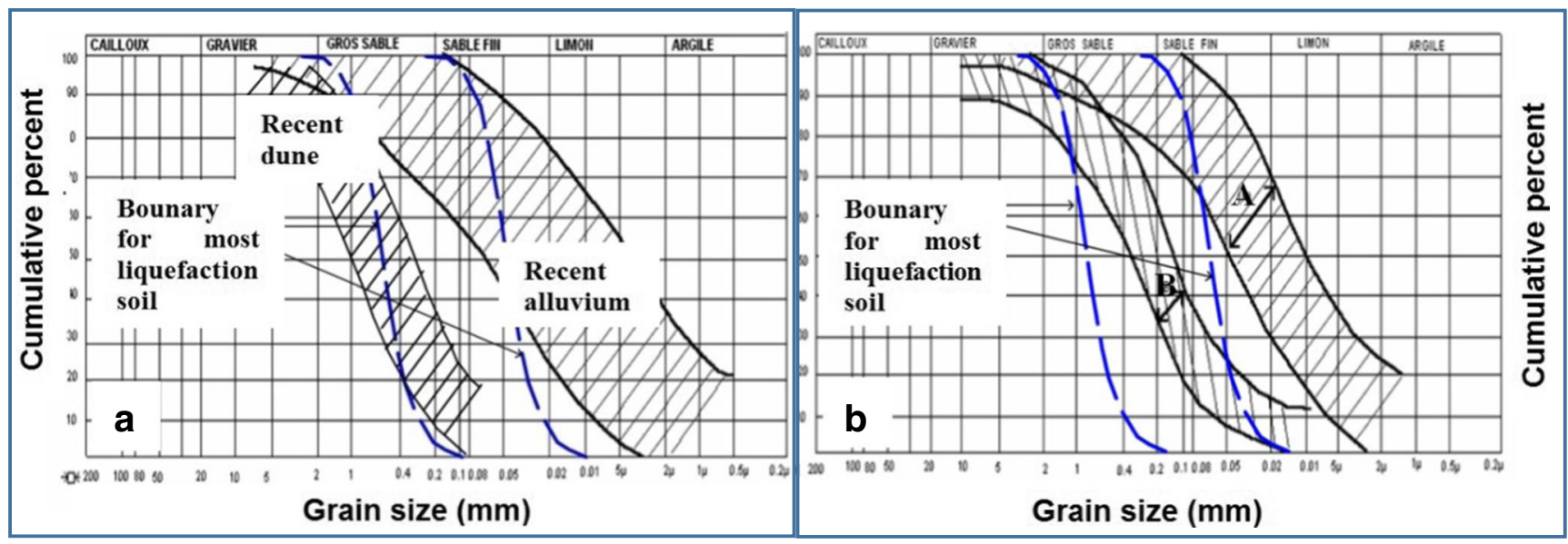

Fig. 10 Comparison between the grain size distribution of the susceptible to liquefaction soil layers in the city of Boumerdès and the boundaries for most liquefiable soils: a) recent dune and recent alluvial; b) Pleistocene red sand

(ii) Data from in situ tests and analyses indicating that the soils are likely to liquefy; (iii) Area containing late Holocene age soils, groundwater table at $<13 \mathrm{~m}$ of depth and the ground motion acceleration (PGA) having a probability of $10 \%$ of being exceeded in 50 years greater than $0.1 \mathrm{~g}$; (iv) Holocene age soils with groundwater table depth less than $10 \mathrm{~m}$ and the PGA probability (10\% in 50 years) greater than $0.2 \mathrm{~g}$.

By considering the above mentioned criteria, the area of Boumerdès appears as a site of high seismicity, the design acceleration (PGA) of the new Algerian seismic code is equal to $0.30 \mathrm{~g}$, having a $10 \%$ probability of being exceeded in 50 years (RPA 2003). Furthermore, the Zemmouri earthquake of May 21, 2003 (Mw 6.8) induced extensive liquefaction phenomena (Bouhadad et al. 2004; Machane et al. 2004) and evidences of paleoliquefaction of seismic origin were also found and described in the urban area of Boumerdès (Bouhadad et al. 2008) (Fig. 12). Therefore, liquefied soil areas in the past will help us to identify areas that could be liquefied during future earthquakes (Youd 1998). In addition, the city of
Boumerdès appears as built on the loose dunes sands, actual alluvial, Holocene recent alluvial, and Pleistocene sandy clays as shown on the geological map of Fig. 7. These deposits are classified as liquefiable if saturated according to Youd and Perkins (1978). On the other hand, water points depth data indicate that the ground water table is at a depth of 0.5 to $20 \mathrm{~m}$ (Fig. 8).

\section{Geoetchnical susceptibility}

Seed et al. (2003) showed that soils are liquefiable when the following criteria are mainly checked: (i) a degree of saturation $(\mathrm{Sr})$ close to $100 \%$, (ii) a fraction of the fine $(\mathrm{FC})$ less than $35 \%$, (iii) The grains size diameter lies between $0.05 \mathrm{~mm}$ and $1.5 \mathrm{~mm}$, and uniform granulometry that correspond to a coefficient of uniformity $\mathrm{Cu}<15$. The statistical summary of all these geotechnical parameters is given in Table 2. Following the granulometry results, the SPT tests and the number of corrected blows, we observe the following (Table 2): (1) Saturation in current dunes (Ad) is about $96 \%$, for the

Table 2 Statistical soil parameters analysis results of Boumerdès area

\begin{tabular}{|c|c|c|c|c|c|c|c|}
\hline Soil parameters & $\begin{array}{l}\mathrm{Fc} \\
(\%)\end{array}$ & $\begin{array}{l}\mathrm{Sr} \\
(\%)\end{array}$ & $\begin{array}{l}\gamma \mathrm{d} \\
\left(\mathrm{t} / \mathrm{m}^{3}\right)\end{array}$ & $\begin{array}{l}\text { PL } \\
(\%)\end{array}$ & $\begin{array}{l}\mathrm{LL} \\
(\%)\end{array}$ & $\begin{array}{l}\text { Vs } \\
(\mathrm{m} / \mathrm{s})\end{array}$ & $\mathrm{N}_{\mathrm{SPT}}$ \\
\hline \multirow[t]{2}{*}{ Lithology } & Min-Max & Min-Max & Min-Max & Min-Max & Min-Max & Min-Max & Min-Max \\
\hline & Average & Average & Average & Average & Average & Average & Average \\
\hline \multirow[t]{2}{*}{ Sandy dune (ad) } & $1-20$ & $91-100$ & $1,07-1,54$ & $15-21$ & $30-41$ & $240-500$ & $9,8-60$ \\
\hline & 6,6 & 95 & 1,34 & 18 & 35 & 370 & 44,12 \\
\hline \multirow[t]{2}{*}{ Holocene sandy clays $\left(\mathrm{a}_{2}\right)$} & $1-98$ & $87-99$ & $1,13-1,79$ & $18-29$ & $37-52$ & $170-360$ & $9,8-60$ \\
\hline & 66 & 92 & 1,51 & 24 & 47,6 & 236 & 43 \\
\hline \multirow[t]{2}{*}{ Pleistocene clayey sand (as) } & $1-87$ & $82-100$ & $1,32-2,24$ & $5-55$ & $13-52$ & $172-730$ & $4-60$ \\
\hline & 36 & 90 & 1,77 & 18,62 & 34,92 & 503 & 32 \\
\hline
\end{tabular}

$F c$ Fraction of the fines particles, $S r$ Degree of saturation, $\gamma d$ Dry density, LL Liquidity limit, PI Plasticity limit, $V s$ Velocity, $N_{S P T}$ Standard penetration test 


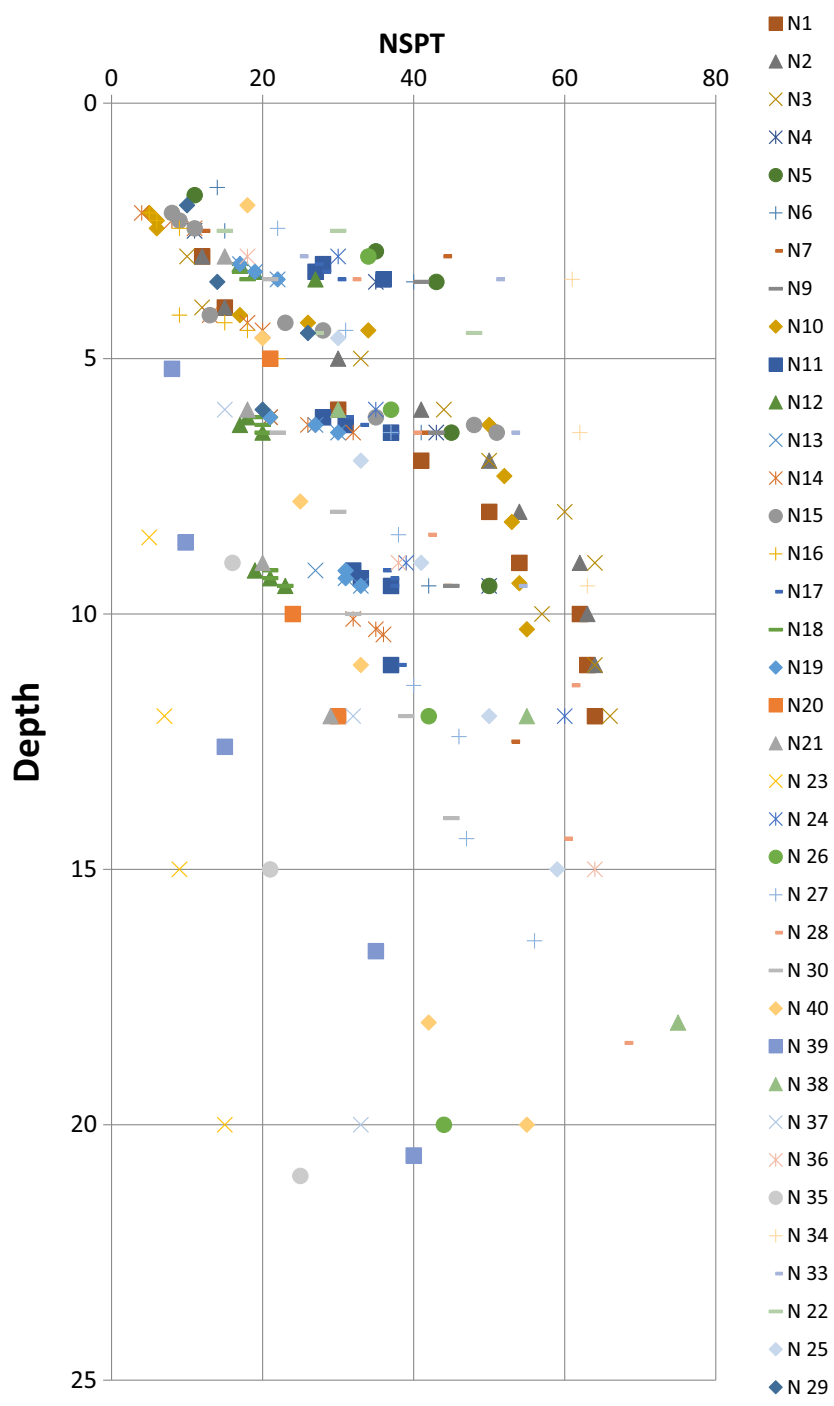

Fig. 11 Distribution of N SPT values in function of the depth

Holocene recent alluvial $\left(a_{2}\right) 90 \%$ and a high saturation of $90 \%$ to $100 \%$ for Pleistocene red sands (as), (2) Granulometric curves shows that the granulometric characteristics falls in liquefiable conditions (Fig. 10): (i) a fraction of the fines particles (FC) ranges between $4 \%$ to $38 \%$ for Pleistocene red sands, from $1 \%$ to $50 \%$ for recent alluvial, and from $1 \%$ to $54 \%$ for the current dunes sands, (ii) $70 \%$ to $90 \%$ of the particles have a diameter ranging between $1 \mathrm{~mm}$ to $0.08 \mathrm{~mm}$, (iii) the diameter with $50 \%$, D50, is included/ understood between $0.15-0.7 \mathrm{~mm}$ for the recent dunes, between $0.01-0.6 \mathrm{~mm}$ for the Holocene recent alluvial sand, and $0.02-0.4 \mathrm{~mm}$ for Pleistocene red sands, (iv) the coefficient of uniformity (CU) lies between 1 to 3 for the clean sands and badly graduated $(\mathrm{Sm})$ according to the soil classification (LCP). These results show that the studied region soil is likely liquefiable except for the metamorphic basement and the plastic Plaisancian marls. The soils that require potential liquefaction assessment are the recent deposits of (as), (ad), and (a2).
On the other hand, the plasticity behavior of fine grained particles of soils is more important than the clay size fraction. Thus, they showed that soils are considered as probably liquefiable when the (LL) is less than $37 \%$ and the (PL) is less than 12\% (Seed et al. 2003; Bray and Sancio 2006; Idriss and Boulanger 2008). Figure 13 shows the soil units distribution based on their (LL) and (PL). There is a clear distinction between liquefiable and no liquefiable soils based on their liquidity and plasticity limits. The analysis shows that the non-liquefiable soil coincides with the Plaisancian marls unit and the clays contained in the Pleistocene red sands unit, characterized by high plasticity. The majority of the nonliquefiable soils show (LL) values up to $60 \%$ and (PL) values up to $40 \%$. Liquefiable soils correspond to the sand dunes, the Holocene recent alluvial and the Pleistocene sands.

\section{Evaluating liquefaction potential}

In order to evaluate liquefaction occurrence in a given deposit the widely used methodology is that proposed by Iwasaki et al. (1982). The objective consists of the assessment of liquefaction hazard and the compilation of a map showing the spatially distributed probability of liquefaction-induced surface disruption in the studied area. This method is an improved version of the prior method developed by Seed et al. (1971) entitled "simplified procedure", that was modified by Seed et al. (1985) and Youd et al. (2001). It consists of calculating the safety factor per layer (Fs), as the ratio of cyclic resistance ratio (CRR) to the cyclic stress ratio (CSR).

$\mathrm{Fs}=\mathrm{CRR} / \mathrm{CSR}$

The CRR is computed by the following equation:

$\mathrm{CRR}=\frac{1}{34-\left(\mathrm{N}_{1}\right)_{60}}+\frac{\left(\mathrm{N}_{1}\right)_{60}}{135}+\frac{50}{\left(10\left(\mathrm{~N}_{1}\right)_{60}+45\right)^{2}}-\frac{1}{200}(3)$

Where $\left(\mathrm{N}_{1}\right)_{60}$ is the penetration resistance corrected $\left(\mathrm{N}_{1}\right)_{60}=\mathrm{N}_{\mathrm{m}} \mathrm{C}_{\mathrm{n}} \mathrm{C}_{\mathrm{e}} \mathrm{C}_{\mathrm{b}} \mathrm{C}_{\mathrm{r}} \mathrm{C}_{\mathrm{s}}$ ) and standardized relative to the overburden pressure factor $(\mathrm{Cn})$, the correction for hammer energy ratio $(\mathrm{Ce})$, the correction for borehole diameter $(\mathrm{Cb})$, the correction factor for rod length $(\mathrm{Cr})$, and the correction for samplers with or without liners $\left(\mathrm{C}_{\mathrm{s}}\right)$. The $(\mathrm{Cn})$ was calculated according to the equation proposed by Liao and Whitman (1986), $\mathrm{Cn}=\left(\mathrm{Pa} / \sigma^{\prime} \mathrm{v}\right)^{0.5}$ in function with $(\mathrm{Pa})$ (atmospheric pressure) and the $\sigma$ 'v (effective vertical stress). Additionally, a "fine content" correction was applied to the calculated N1(60) value in order to obtain an equivalent clean sand value $\mathrm{N} 1(60)$ cs given by the equations proposed by Youd et al. (2001). 
Fig. 12 Distribution of liquefaction during the main shock of the May 21, 2003( $(\mathrm{Mw}=6.8)$ Zemmouri earthquake (Inset) and the observed paleo-liquefaction in the studied area (Bouhadad et al. 2004; Machane et al. 2004; Bouhadad et al. 2008). Letters (ad) indicate the location of photographs of Fig. 1 (a-d)

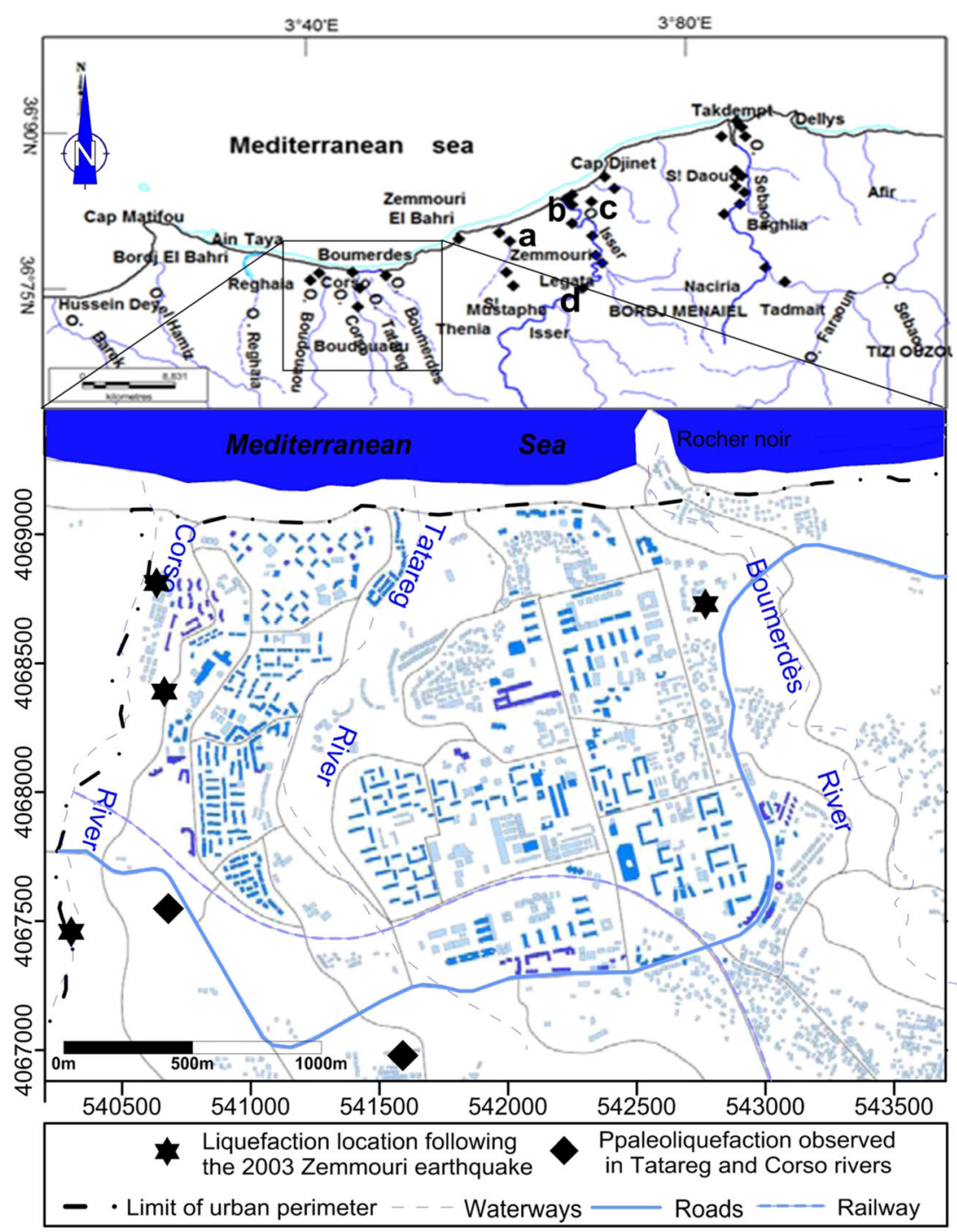

The CSR defines the seismic demand and is expressed as:

$C S R=0.65\left(\frac{a_{\mathrm{max}}}{g}\right)\left(\frac{\sigma_{V}}{\sigma_{V}^{\prime}}\right) r_{d}$

Where $\sigma \mathrm{v}$ is the total vertical stress at depth $\mathrm{z}, \sigma$ 'v is the effective vertical stress at the same depth, $a_{\max }$ is the peak horizontal ground acceleration, $(\mathrm{g})$ is the acceleration due to gravity, and (rd) is the stress reduction factor. The term (rd) was estimated using the Liao and Whitman (1986) equation:

$r_{d}=1,0-0,00765 \mathrm{Z}$ for $\mathrm{Z} \leq 9,15 \mathrm{~m}$

$r_{d}=1,174-0,0267 \mathrm{Z}$ for $9,15<Z \leq 23 \mathrm{~m}$

The CSR values have been divided by the magnitude scaling factor (MSF), which is calculated by the following equation of Youd et al. (2001):

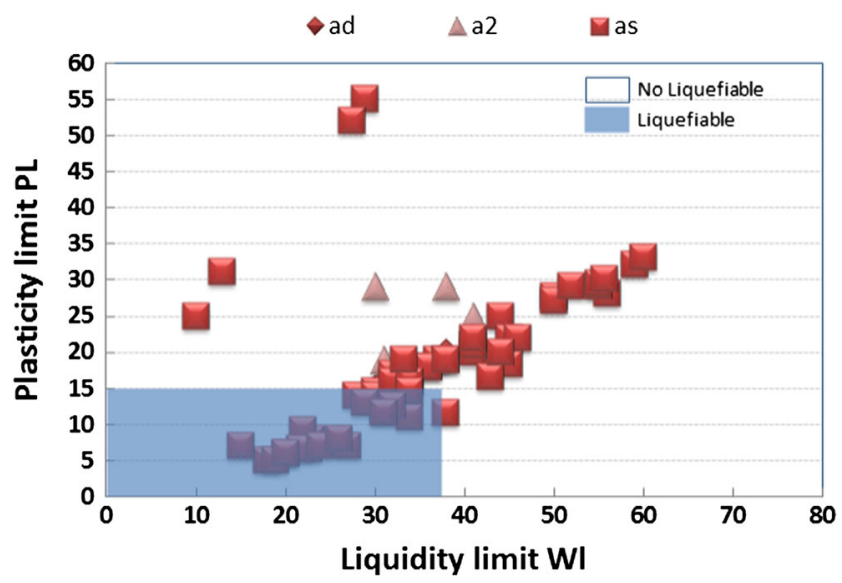

Fig. 13 Analysis of the liquefaction susceptibility based on the criteria proposed by Seed et al. (2003). Blue rectangle is plotted to show the susceptible areas to soil liquefaction while the white area indicate the non-liquefiable ones 


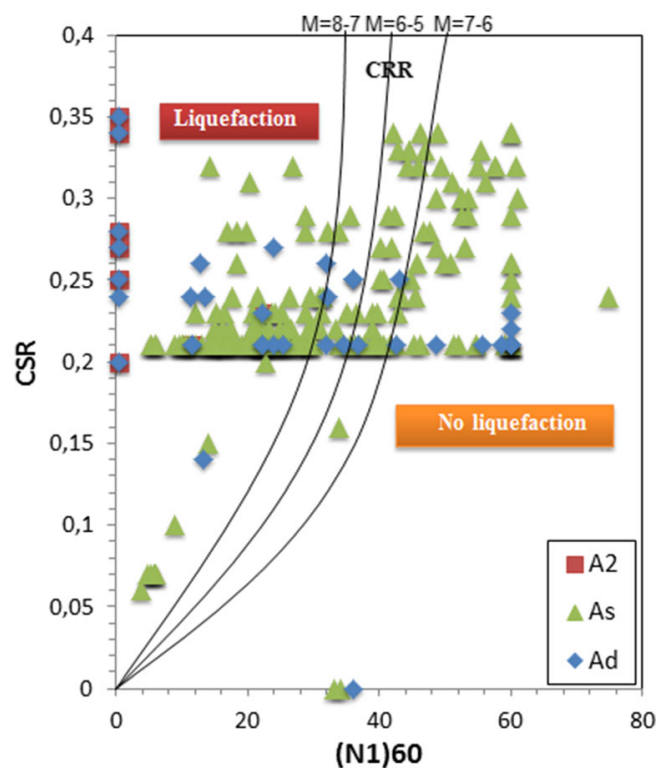

Fig. 14 Relation between the cyclic stress ratio (CSR) and the penetration resistance corrected $\left(\mathrm{N}_{1}\right)_{60}$ indifferent lithological units of Boumerdès city (Seed et al. 1985)

$\mathrm{MSF}=(\mathrm{Mw} / 7.5)^{2,56}$

Afterward, the values of liquefaction potential index (LPI) of the soil columns for a given site at a depth of $20 \mathrm{~m}$ and for boreholes were computed using the following equation of Iwasaki et al. (1982):

LPI $=\int_{0}^{20} F(z) w(z) d z$

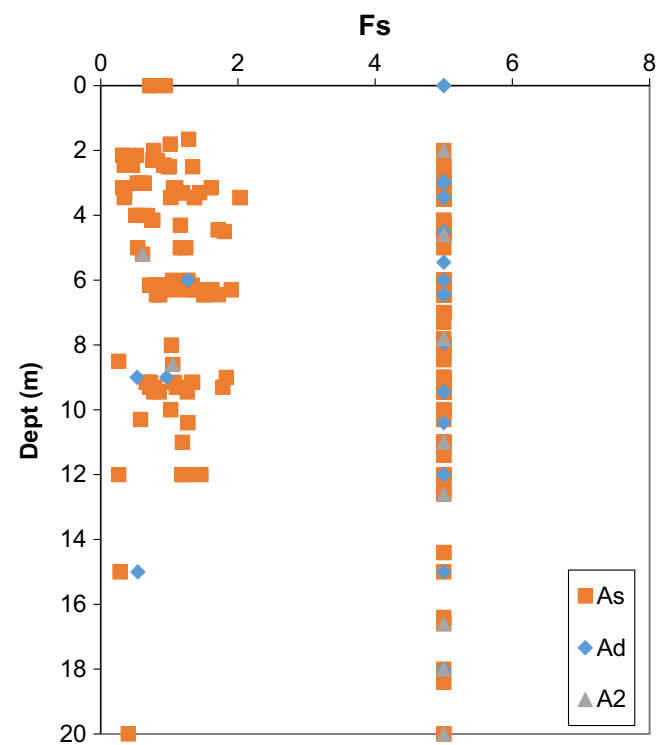

Fig. 15 Results of the safety factor (Fs) calculation according to the depth for different lithological units in the city of Boumerdès: recent dune (ad),-Holocene alluvium $\left(\mathrm{a}_{2}\right)$, Pleistocene red sand(as)

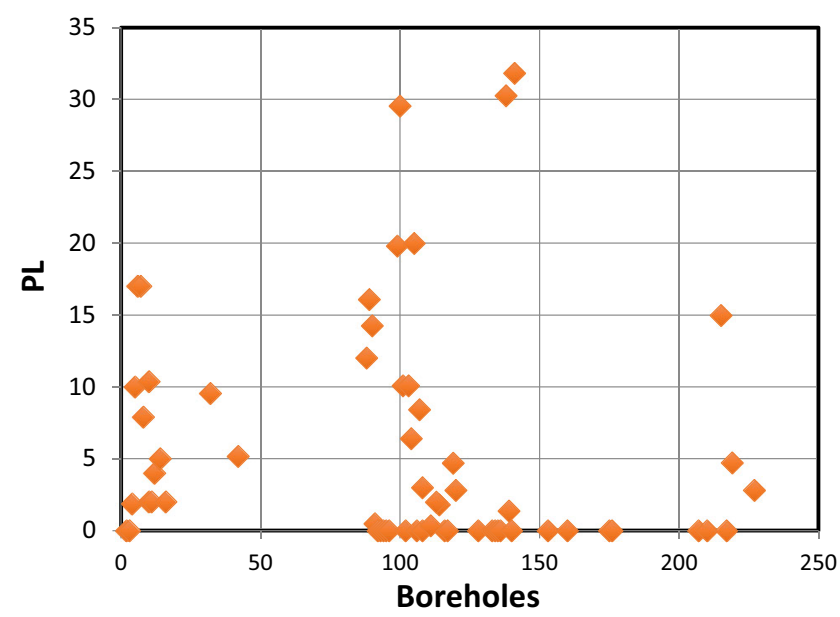

Fig. 16 The computed (LPI) values per boreholes induced ground disruption at the city of Boumerdès for a seismic hazard scenario corresponding to $\mathrm{a}_{\max }=0.48 \mathrm{~g}$

Where $(z)$ is the depth below the ground surface in meters and is calculated as $\mathrm{w}(\mathrm{z})=10-0.5 \mathrm{z} ; \mathrm{F}(\mathrm{z})$ is a function of the safety factor against liquefaction, $(\mathrm{Fs})$, where $\mathrm{F}(\mathrm{z})=1-\mathrm{Fs}$ when Fs $<1$ and $\mathrm{F}(\mathrm{z})=0$ when Fs $>1.0)$.

Iwasaki et al. (1982) calibrated the severity of liquefaction induced damages with the (LPI) values. According to this calibration, no evidence of liquefaction phenomena are expected where $0 \leq$ LPI, while moderate and high degree of liquefaction surface deformations are expected where (LPI) values range between 5 and 15 and LPI $>15$. The advantage of (LPI) is that it quantifies the likelihood of liquefaction at the site by providing a unique value for the entire soil column instead of factors of safety for each of the layers. Consequently, the (LPI) values were used for the compilation of liquefaction hazard maps which can be used by planners as a tool for the preliminary assessment of the liquefaction potential. The liquefaction assessments in Boumerdès city has been performed by using data from geotechnical profiles of 154 boreholes with 56 SPT tests and 35 water points leveling and a seismic scenario of $\mathrm{Mw}=7.3$, taken from the seismic hazard study. By computing the CRR of the soil layers and the CSR (Fig. 14) regarding the earthquake "scenario", the safety factor against liquefaction (Fs) was calculated (Fig. 15). Then, the depth and the thickness of the liquefied layers, per borehole, were defined based on the computed values of (Fs) of the soil layers. The depth of the liquefiable layer is evaluated by considering the depth of the upper subsoil layer susceptible to liquefaction, for which the safety factor was estimated less than one $(F s<1)$. Figure 15 summarizes results of the safety factor (Fs) calculation as a function of the depth for the different lithological units in the studied area. The obtained results indicate that the Pleistocene coarse sands are liquefiable at shallow depth $(1-5 \mathrm{~m})$ for the accelerations $\mathrm{a}_{\max }=0.48 \mathrm{~g}$, while the recent dune and sand Holocene alluviums are liquefiable at a depth of 1-10 m. 
Fig. 17 Liquefaction hazard map of Boumerdès city for a seismic hazard scenario corresponding to $\mathrm{a}_{\max }=0.48 \mathrm{~g}$

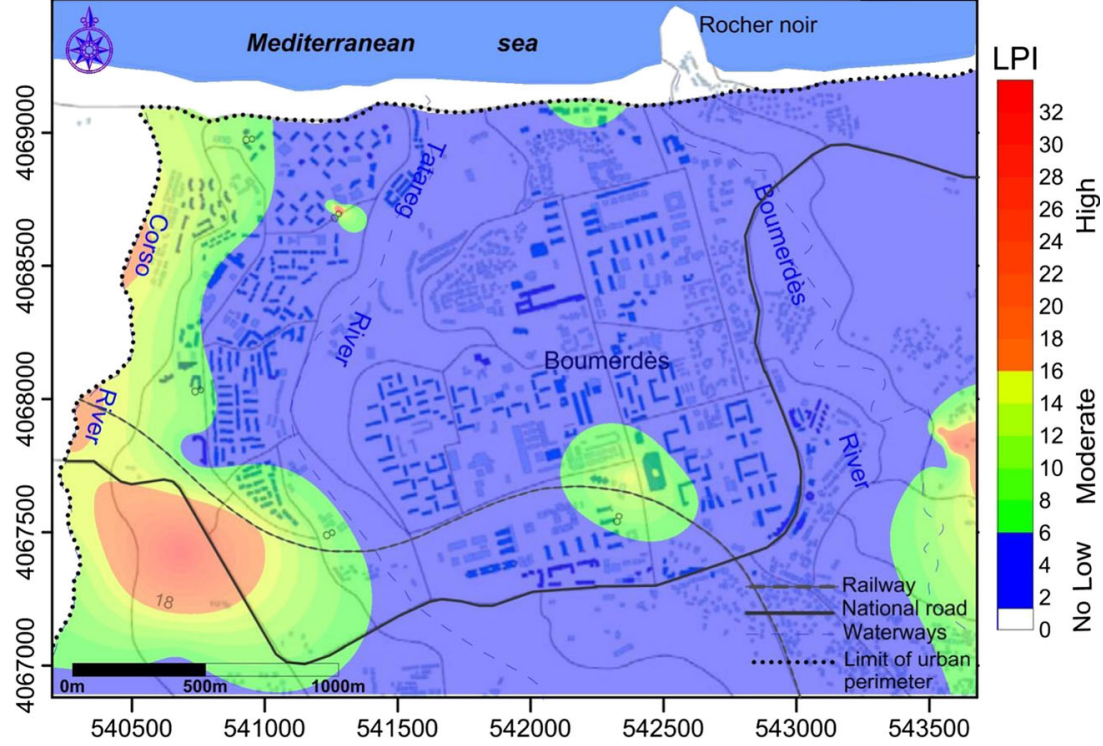

Liquefaction potential mapping

After computing the safety factor (Fs), the values of liquefaction potential index (LPI) of the soil columns for a given site at a depth of $20 \mathrm{~m}$ and for boreholes have been calculated using Eq. 8 cited above. The results from liquefaction potential analysis show that the (LPI) index, varying from 0 to 32 , fluctuates horizontally according to the accelerations values (Fig. 16). The obtained results suggest that the moderate and high liquefaction area have been observed in the sand layer characterized by moderate and high susceptibility to liquefaction, particularly, along the Corso waterway at the west of Boumerdès city. These results also show a good agreement with the observations made during the May 21, 2003 $(\mathrm{Mw}=6.8)$ Zemmouri earthquake (Bouhadad et al. 2004; Machane et al. 2004; Bouhadad et al. 2008). The obtained results are also compatible with the geological, geotechnical, and hydrogeological susceptibility to liquefaction of the area (Youd and Perkins 1978).
Liquefaction potential mapping of the study area is obtained by correlation (e.g., krigging) of the liquefaction potential index (LPI) obtained for each borehole and for the above mentioned scenario (Fig. 17). The map shows that liquefaction is low in the center and in the east of the city corresponding to clay soils, bedrock, and dense sand with a deep water table (generally higher than $12 \mathrm{~m}$ ). The liquefaction potential is moderate to high in the West of the city corresponding to areas formed by sand deposits, fairly dense and relatively loose, of the alluvial plain, characterized by a shallow water table (ranging between 0 to $10 \mathrm{~m}$ ). Liquefaction is quite apparent in the West of the city (Fig. 17), in the alluvial plain of the Corso waterway, where the geological and the hydrogeological conditions are favorable, a shallow water table, and thick loose sandy layers. This observation has
Fig. 18 Spatial distribution of the probability of liquefactioninduced surface disruption for seismic scenario of $\mathrm{a}_{\max }=0.48 \mathrm{~g}$

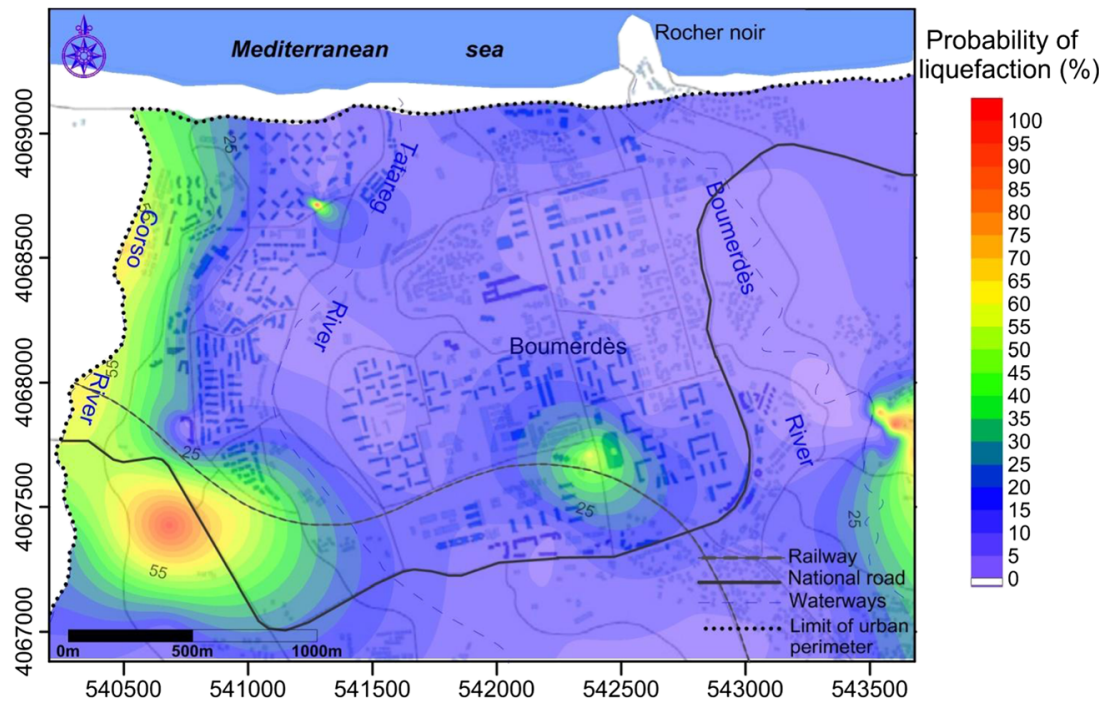


been confirmed by the observations of liquefaction during the May 21, $2003(\mathrm{Mw}=6.8)$ earthquake (Fig. 10). The susceptibility to liquefaction decreases with the distance from waterways where the water table is shallow (6 to $8 \mathrm{~m}$ ). Moderate susceptibility is observed where the water table depth is less than $10 \mathrm{~m}$. Non susceptible area corresponds to the anteHolocene deposits where the water table depth is more than $10 \mathrm{~m}$. Liquefaction impact depends on the level of susceptibility. In the high susceptibility area the consequences are represented by lateral spreading near free surfaces and settlement. In the moderately susceptible area the settlement is less while in weak susceptibility the impact is minor. Consequently, before any project of construction in liquefiable soils we need necessarily either to strengthen the site or to avoid it.

The computed values of (LPI) at each location of each borehole were used in the equation proposed by Papathanassiou (2008) to evaluate the probability of liquefaction-induced ground disruption:

$$
\text { Probability }(\text { liquefaction })=\left(1 / 1+e^{-(-3.092+0.218 x L P I}\right)
$$

The aim of the present study was, therefore, the assessment of liquefaction hazard and the compilation of a map showing spatially distributed probability of liquefaction-induced surface disruption. In this model, the (LPI) value is the independent variable and the occurrence or not of liquefaction phenomena is the dependent one. At sites where the probability $(\mathrm{P}) \geq 0.5$ liquefaction phenomena are expected to be triggered while non-occurrence of liquefaction is predicted where $P<0.5$ (Fig. 17). In our study, as shown in Fig. 18 for $\mathrm{a}_{\max }=0.48 \mathrm{~g}$, the probability of liquefaction-induced ground failures is very low at the city of Boumerdès, with the computed value of probability $>50 \%$, and concerns only the sites close to the Corso River plain. For the other sites of Boumerdès city, liquefaction phenomena is not expected at the surface under a seismic loading $\mathrm{a}_{\max }=0.48 \mathrm{~g}$. The defined liquefaction model is almost the same as the defined one by the (LPI) values (Fig. 16).

\section{Discussions and conclusion}

The city of Boumerdès is located in the seismically active zone of Northern Algeria. Indeed, the peak ground acceleration (PGA) provided by the Seismic hazard study is $0.48 \mathrm{~g}$ for a return period of 500 years. During the May 21, 2003 $(\mathrm{Mw}=6.8)$ Zemmouri earthquake liquefaction was extensively observed in the most susceptible areas around Boumerdès city, where the geological, geotechnical, and hydrogeological conditions are most favorable. In this study, we used geological, geotechnical, and hydrogeological data, gathered from boreholes and standard penetrations tests (SPT) to assess the liquefaction potential of the subsoil layers by applying the methodology of liquefaction potential index (LPI) and by considering the seismic scenario, represented by the maximum peak ground accelerations (PGA). The scenario corresponds to the $\mathrm{a}_{\max }=0.48 \mathrm{~g}$ provided by the seismic hazard study of the area. Results are shown as liquefaction hazard maps by using the classification of (LPI) values that provide the severity of liquefaction surface evidence and the computed probability of liquefaction-induced surface disruption. The obtained maps show the quantitative characteristics of the liquefiable layers and the area where there is a probability of surface evidence of liquefaction. Our results conclude that the urban area of Boumerdès city exhibits a low potential of liquefaction, except for the Corso waterway valley located at the west of the city, where the liquefaction potential is moderate to high. Our results also show that the observed liquefaction during the May 21, $2003(\mathrm{Mw}=6.8)$ earthquake fall into the area of high and moderate liquefaction potential. The obtained liquefaction hazard maps may serve as useful tools for land management and planning in the city and as a study-example to follow in other populated cities of northern Algeria located in earthquake and liquefaction prone areas.

Acknowledgements This work is supported by the CGS (Centre National de Recherche Appliquée en Génie Parasismique) of Algiers (Seismic microzonation study of urban areas in Boumerdès) and the University of USTHB (Université des Sciences et de la Technology Houari Boumediene Bab Ezzouar) of Algiers. The authors would like to express their thanks and gratitude to the local companies (L.C.T.P, L.N.H.C and ANRH) for providing geotechnical and hydrogeological datasets. The authors are also grateful to the anonymous reviewers for their constructive comments that helped in improving this paper.

Open Access This article is distributed under the terms of the Creative Commons Attribution 4.0 International License (http:// creativecommons.org/licenses/by/4.0/), which permits unrestricted use, distribution, and reproduction in any medium, provided you give appropriate credit to the original author(s) and the source, provide a link to the Creative Commons license, and indicate if changes were made.

\section{References}

AFPS French association for earthquake engineering (1995) Guidelines for seismic microzonation studies

Agence Nationale des Ressources Hydriques (ANRH) (2007) Inventory of water points of Boumerdès city for the period of April 2007

Akkar S, Bommer JJ (2010) Empirical equations for the prediction of PGA, PGV and spectral accelerations in Europe, the Mediterranean region and the Middle East. Seismol Res Lett 81(2):195-206

Ambraseys NN (1988) Engineering seismology. Earthquake Eng StructDyn 17:1-105. https://doi.org/10.1002/eqe. 4290170101

Ambraseys NN, Bommer JJ (1991) The attenuation of ground accelerations in Europe. Earthq Eng Struct Dyn 20:1179-1202

Ambraseys NN, Douglas J, Sarma SK, Smith PM (2005) Equations for the estimation of strong ground motions from shallow crustal 
earthquakes using data from Europe and the Middle East: horizontal peak ground acceleration and spectral acceleration. Bull Earthq Eng $3(1): 1-53$

Aoudia A, Meghraoui M (1995) Seismotectonics in the tell atlas of Algeria: the Cavaignac (Abou el Hassan) earthquake of august 25, $1922(\mathrm{M}=5.9)$. Tectonophysics 248:263-276

Argus DF, Gordon RG, De Mets C, Stein S (1989) Closure of the AfricaEurasia-North America plate motion circuit and tectonics of the Glauria fault. J Geophys Res 94:5585-5602

Ayadi A, Bezzeghoud M (2015) Seismicity of Algeria from 1365 to 2013: maximum observed intensity map (MOI2014). Seismol Res Lett 86(1). https://doi.org/10.1785/0220140075

Ayalew L, Yamagishi H (2005) The application of GIS-based logistic regression for landslide susceptibility mapping in the KakudaYahiko Mountains, Central Japan. Geomorphology 65:15-31

Belabbes S, Wicks C, Cakir Z, Meghraoui M (2009) Rupture parameters of the 2003 Zemmouri (mw 6.8)Algeria earthquake from joint inversion of interferometric synthetic aperture radar, coastal uplift, and GPS. J Geophys Res 114:B03406. https://doi.org/10.1029/ 2008JB005912

Benfedda A, Abbes K, Bouziane D, Bouhadad Y, Slimani A, Larbes S, Haddouche D, Bezzeghoud M (2017) The august 1st, 2014 (mw 5.3) moderate earthquake: evidence for an active thrust fault in the bay of Algiers (Algeria). Pure Appl Geophys. https://doi.org/10. 1007/s00024-017-1481-6

Benhammouche A, Nedjari A, Bouhadad Y, Machane D, Oubaiche EH, Sidi Said N (2013) Field evidence of seismites in quaternary deposits of the Jijel (eastern Algeria) coastal region. J Seismology 43:1383-4649. https://doi.org/10.1007/s10950-013-9384-1

Benouar D (1994) Material for the investigation of the seismicity of Algeria and adjacent region during the twentieth century. Annali di Geofisica XXXVII 4:860

Bensalem R, Chatelain JL, Machane D, Oubaiche EH, Hellel M, Guillier B, Djeddi M, DjadiaL (2010) Ambient vibration techniques applied to explain heavy damage caused in Corso (Algeria) by the 2003 Boumerdès earthquake: understanding seismic amplification due to gentle slopes. Seismol Res Lett 81:928-940. https://doi.org/10. 1785/gssrl.81.6.928

Bouhadad Y (2001) The Murdjadjo, western Algeria, fault-related fold: implication for seismic hazard. J of Seismology 5:541-558. https:// doi.org/10.1023/A:1012039900248

Bouhadad Y (2013) Occurrence and impact of characteristic earthquakes in Algeria. Nat Hazard. https://doi.org/10.1007/ s11069-013-0704-0

Bouhadad Y, Laouami N (2002) Earthquake hazard assessment in the Oran region (northwest Algeria). J Nat Hazard 26(3):227-243

Bouhadad Y, Nour A, Slimani A, Laouami N, Belhai D (2004) The Boumerdès (Algeria) earthquake of may 21, $2003 \mathrm{mw}=6.8$ : ground deformation and intensity. J Seismology 8:497-506. https://doi.org/ 10.1007/s10950-004-4838-0

Bouhadad Y, Benhammouche A, Maouche S, Belhai D (2008) Evidence for quaternary liquefaction-induced features in the epicentral area of the 21 may 2003 Zemmouri earthquake (Algeria, MW = 6.8). J Seismology 13:161-172

Bouhadad Y, Benhammouche A, Bourenane H, Ait Ouali A, Chikh M, Guessoum N (2010) The Laalam (Algeria) damaging landslide triggered by a moderate earthquake $\left(\mathrm{M}_{\mathrm{w}}=5.2\right)$. Nat Hazards 54:261272

Bounif A, Dorbath C, Ayadi A, Meghraoui M, Beldjoudi H, Laouami N, Frogneux M, Slimani A, Alasset PJ, Kharroubi A, Oussadou F, Chikh M, Harbi A, Larbes S, Maouche S (2004) The may 2003 Zemmouri (Algeria) earthquake $\mathrm{mw}=6.8$ : relocation and aftershock sequence analysis. GeophysResLett 31:L19605

Bourenane H. (2010) Utilisation de l'analyse statistique dans l'interprétation des paramètres géotechniques ; Application à l'étude de microzonage sismique de la région de Boumerdès.
Mémoire de Magister en Géologie, Spécialité géologie appliquée aux études et travaux de génie civil, USTHB d'Alger

Bourenane, H, Bouhadad, Y., Guettouche M.S., Braham, M. (2014) GISbased landslide susceptibility zonation using bivariate statistical and expert approaches in the city of Constantine (Northeast Algeria)". doi: 10.1007/s10064-014-0616-6

Bourenane H, Guettouche MS, Bouhadad Y, Braham M (2016) Landslide hazard mapping in the Constantine city, Northeast Algeria using frequency ratio, weighting factor, logistic regression, weights of evidence, and analytical hierarchy process methods. Arab J Geosci 9:154. doi:10.1007/s12517-015-2222-8

Bray J, Sancio R (2006) Assessment of the liquefaction susceptibility of fine-grained soils. J Geotech Geoenviron Eng 132(9):1165-1177

Carrara A, Cardinali M, Guzzetti F, Reichenbach P (1995) GIS technology in mapping landslide hazard. In: Geographical information systems in assessing natural hazards. Kluwer, dordrecht, pp 135-175

CDMG (1999) Guidelines for analyzing and mitigating liquefaction hazards in California. California Dept Conservation, Division of Mines and Geology, Special Publication 117, p 63

CGS (2009) Seismic microzonation study of urban areas in Boumerdès City, Report, Centre National de Recherche Appliquée en Génie Parasismique, CGS. Rapport interne

Cornell CA (1968) Engineering seismic risk analysis. Bul, Seism Soc, Am 58:1583-1606

Déverchère J, Yelles K, Domzig A, Mercier de Lepinay B, Bouillin JP, Gaulier V (2005) Active thrust faulting offshore, Boumerdès, Algeria, and its relations to the $2003 \mathrm{mw}=6.9$ earthquake. Geophys Res Lett 32:L04311. https://doi.org/10.1029/ 2004GL021646

Direction du Logement et des Équipements Publics de la Wilaya de Boumerdès (DLEP) (2004) Conséquences du séisme sur le parc logement et les équipements publics, Direction du Logement et des Équipements Publics de la Wilaya de Boumerdès

Dunand F, Ait MY, Gueguen P, Chatelain JL, Guillier B, Ben SR, Hadid M, Hellel M, Kiboua A, Laouami N, Machane D, Mezouer N, Nour A, Oubaiche EH, Remas A (2004) Utilisation du bruit de fond pour l'analyse des dommages des bâtiments de Boumerdès suite au séisme du 21 mai 2003. Mémoire du Service Géologique de l'Algérie 12:177-191

Ficheur (1895) Carte géologique de Thénia (ex. Menerville) au 1/50 $000 \mathrm{~N}^{\circ} 22$

Geomatrix Consultants (1993) Probabilistic seismic hazard analysis computer program: a user manual. Geomatrix Consultants, Denver

Guillier B, Machane D, Oubaiche E, Chatelain JL, Ait MY, Ben SR, Dunand F, Guéguen P, Hadid M, Hellel M, Kibboua A, Laouami N, Mezouer N, Nour A, Remas A (2004) Résultats préliminaires sur les fréquences fondamentales et les amplification de sols, obtenus par l'étude du bruit de fond, sur la ville de Boumerdès - Algérie. Mémoire du Service Géologique d'Algérie 12:103-114

Harbi A. (2001) Analyse de la sismicité et mise en évidence d'accidents actifs dans le Nord-EstAlgérien. Thèse de Magistère, USTHB, 189 pp

Hellel M, Chatelain JL, Guillier B, Machane D, Ben Salem R, Oubaiche H, Haddoum H (2010) Heavier damages without site effects and site effects with lighter damages: Boumerdès City (Algeria) after the may 2003 earthquake. J Seismological Res Lett 81:37-43. https:// doi.org/10.1785/gssrl.81.1.37

Idriss IM, Boulanger RW (2008) Soil liquefaction during earthquakes. Earthquake Engineering Research Institute, Oakland

Iwasaki T, Tokida K, Tatsuoka F, Watanabe S, Yasuda S, Sato H (1982) Microzonation for soil liquefaction potential using simplified methods. In: Proc 3rd International Conference on microzonation. Seattle 3:1310-1330

L.C.T.P Laboratoire National des Travaux Publics Études géotechniques des sols (1988-2003). Rapports internes

L.N.H.C Laboratoire National d'habitat et de construction (1980-2010) Rapports internes 
Laouami N, Slimani A, Bouhadad Y, Nour A, Larbes S (2003) Analysis of strong ground motions recorded during the 21st May, 2003 Boumerdès. Algeria, Earthquake, CSEM Newsl 20:5-7

Laouami N, Slimani A, Bouhadad Y, Chatelain JL, Nour A (2006) Evidence for fault-related directionality and localized site effects from strong motion records of the 2003 Boumerdès (Algeria) earthquake: consequences on damage distribution and the Algerian seismic code. Soil Dyn EarthqEng 26:993-1003

Liao S, Whitman RV (1986) Overburden correction factor for SPT in sand. J Geotech Eng ASCE 112(3):373-377

Machane D, Bouhadad Y, Oubaiche EH, Hellel M, Amrouche F, Abbès K, Messaoudi M, Cheikhlounis G (2004) Description morphologique des effets induits par le séisme de Boumerdès (Algérie) du 21 Mai $2003(\mathrm{mw}=6.8)$. Mémoires du Service Géologique d'Algérie 12:133-146

Maouche S, Meghraoui M, Morhange C, Belabbes S, Bouhadad Y, Haddoum H (2011) Active coastal thrusting and folding, and uplift rate of the Sahel anticline and Zemmouri earthquake area (tell atlas, Algeria). Tectonophysics 509:69-80. https://doi.org/10.1016/j.tecto. 2011.06.003

Maouche S, Meghraoui M, Morhange C, Belabbes S, Bouhadad Y, Haddoum H (2013) Reply to the comment of Pedoja et al. by Maouche S, Meghraoui M, Morhange C, Belabbes S, Bouhadad Y, Haddoum H on the published paper: Maouche S, Meghraoui M, Morhange C, Belabbes S, Bouhadad Y, Haddoum H (2011) Active coastal thrusting and folding, and uplift rate of the Sahel anticline and Zemmouri earthquake area (Tell Atlas, Algeria), Tectonophysics, 509(2011):69-80., Tectonophysics 601(2013): 245-247

McGuire RK (1978) FRISK: computer program for seismic risk analysis using faults as earthquake sources. U.S. Geological Survey. Open file report pp 78-1007

Mc Kenzie D (1972) Active tectonics of the Mediterranean region. Geophys J Royal Astro Soc 30:109-185

Meghraoui M (1991) Blind reverse faulting system associated with the Mont Chenoua-Tipaza earthquake of October 29, 1988 (northCentral Algeria). Terra Nova 3:84-93

Meghraoui M, Philip H, Albarede F, Cisternas A (1988) Trench investigations through the trace of the 1980 el-Asnam thrust fault: evidence for paleoseismicity. BullSeismolSoc Am 78(2):979-999

Meghraoui M, Maouche S, Chemaa B, Cakir Z, Aoudia A, Harbi A, Alasset PJ, Bouhadad Y, Benhamouda F (2004) Coastal uplift and thrust faulting associated with the $(\mathrm{mw}=6.8)$ Zemmouri (Algeria) earthquake of 21 May, 2003. Geophys Res Let 31:119605. https:// doi.org/10.1029/2004GL020466

Meslem A, Yamazaki F, Maruyama Y, Benouar D, Kibboua A, Mehani Y (2012) The effects of building characteristics and site conditions on the damage distribution in Boumerdès after the 2003 Algerian earthquake, earth. Spectra 28:185-216

National Research Council (NRC) (1988) Probabilistic seismic hazard analysis. National Academy Press, Washington D.C.
Nocquet JM, Calais E (2004) Geodetic measurements of crustal deformation in the western Mediterranean and Europe. Pure Appl Geopys 161:661-681. https://doi.org/10.1007/s00024-003-2468-Z

Osmani M. and Ouzerara M. (2004) Le séisme du 21 mai 2003 (Mw=6.8) contribution àl'étude de l'effet de site par mesure du bruit de fond sismique (méthode H/V)- Boumerdès. Mémoired'Ingénieur, USTHB, $115 \mathrm{p}$

Papathanassiou G (2008) LPI-based approach for calibrating the severity of liquefaction-induced failures and for assessing the probability of liquefaction surface evidence. EngGeol 96:94-104

Philip H, Meghraoui M (1983) Structural analysis andinterpretation of the surface deformation of theEl-Asnam earthquake of October 10, 1980. Tectonics 2(1):17-49. https://doi.org/10.1029/ TC002i001p00017

RAAG (1994) Les séismes en Algérie de 1365 à 1992. Publication du Centre de Recherche en Astronomie, Astrophysique et Géophysique, Département Etudes et Surveillance Sismique, ESS, C.R.A.A.G, Alger-Bouzaréah

RPA (2003) Algerian building code, RPA99/2003, DTR-B.C.2.48, Ministry of Housing and Urban Planning, Algeria

Sadigh K., Chang C.Y., Abrahamson N.A., Chiou S.J., Power M.S. (1993) Specification of long period ground motion. Updated attenuation relationships for rock site conditions and adjustment factors for near fault effects. Proc ATC-17-1 seminar on seismic isolation, passive energy dissipation, and active control. March 11-12 San Francisco, pp 59-70

Seed HB, Idriss IM (1971) Simplified procedure for evaluating soil liquefaction potential. J Soil Mech Found Div ASCE 97(SM9):12491273

Seed HB, Tokimatsu K, Harder LF, Chung RM (1985) The influence of SPT procedures in soil liquefaction resistance evaluations. J GeotechEng Div ASCE 111(12):1425-1445

Seed RB, Cetin KO, Moss RES, Kammerer AM, Wu J, Pestana JM, Riemer MF, Sancio RB, Bray JD, Kayen RE, Faris A (2003) Recent advances in soil liquefaction engineering: a unified and consistent framework. In: Proceedings of 26th annual ASCE L.A. Geotechnical Spring Seminar, Long Beach, p 71

Varnes D.J. (1984) Landslide hazard zonation: a review of principal and practice. Commission of Landslide of IAEG, UNESCO. Nat Hazards (3):63

Youd T.L. (1998) Screening guide for rapid assessment of liquefaction hazard at highway bridge site. Technical report, MCEER-19982005, p 58

Youd TL, Perkins DH (1978) Mapping liquefaction-induced ground failure potential. J Geotech Eng Div ASCE 104(GT4):433-446

Youd TL, Idriss IM, Andrus RD, Arango I, Castro G, Christian TV, Dobry R, Finn WDL, Harder LF, Hynes ME, Ishihara K, Koester JP, Liao SSC, Marcurson WF III, Marti GR, Mitchell JK, Moriwaki Y, Power MS, Robertson PK, Seed RB, Stokoe KH II (2001) Liquefaction resistance of soils: summary report from the 1996 NCEER and 1998 NCEER/NSF workshops on evaluation of liquefaction resistance of soils. J Geotech Geoenviron Eng ASCE 127(10):817-833 